\title{
Improving Awareness and Access to Adaptive Sports
}

\author{
Alison S. Takagaki \\ University of St. Augustine for Health Sciences \\ DOI: https://doi.org/10.46409/sr.XHUX9332
}

Follow this and additional works at: https://soar.usa.edu/capstones

Part of the Occupational Therapy Commons, and the Sports Sciences Commons

\section{Recommended Citation}

Takagaki, A. S. (2020). Improving Awareness and Access to Adaptive Sports. [Doctoral project, University of St Augustine for Health Sciences]. SOAR @ USA: Student Capstone Projects Collection. https://doi.org/ 10.46409/sr.XHUX9332

This Capstone is brought to you for free and open access by the Student Research at SOAR @ USA. It has been accepted for inclusion in Student Capstone Projects by an authorized administrator of SOAR @ USA. For more information, please contact soar@usa.edu, erobinson@usa.edu. 
IMPROVING AWARENESS AND ACCESS TO ADAPTIVE SPORTS

by

Alison S. Takagaki

A Capstone Presented in Partial Fulfillment of the Requirement for the Degree of DOCTOR OF OCCUPATIONAL THERAPY

University of St. Augustine for Health Sciences

April, 2020 


\title{
IMPROVING AWARENESS AND ACCESS TO ADAPTIVE SPORTS
}

by

\author{
Alison S. Takagaki \\ has been approved
}

April, 2020

APPROVED:

Susan MacDermott, OTD, OTR/L, Doctoral Coordinator

Becki Cohill, OTD, OTR/L, Doctoral Coordinator

Erin Schwier, EdD, OTD, OTR/L, Program Director

ACCEPTED AND SIGNED:

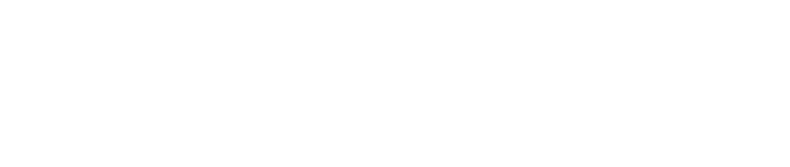

Susan MacDermott, OTD, OTR/L, Doctoral Coordinator

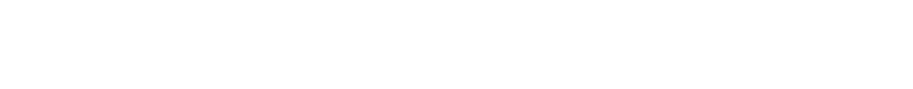

Becki Cohill, OTD, OTR/L, Doctoral Coordinator

Digitally signed by eschwier@usa.edu eschwier@usa.edu DN: cn=eschwier@usa.edu

Date: 2020.04 .25 10:23:07-07'00'

Erin Schwier, EdD, OTD, OTR/L, Program Director 
Table of Contents

$\begin{array}{ll}\text { Chapter I: Introduction } & 5\end{array}$

$\begin{array}{ll}\text { Background } & 5\end{array}$

$\begin{array}{lr}\text { Statement of the Problem } & 9\end{array}$

$\begin{array}{lr}\text { Purpose Statement } & 9\end{array}$

$\begin{array}{ll}\text { Rationale } & 10\end{array}$

$\begin{array}{ll}\text { Significance of the Project } & 13\end{array}$

$\begin{array}{ll}\text { Preliminary Project Objectives } & 14\end{array}$

$\begin{array}{ll}\text { Assumptions } & 15\end{array}$

$\begin{array}{ll}\text { Limitations } & 15\end{array}$

$\begin{array}{ll}\text { Delimitations } & 15\end{array}$

$\begin{array}{lc}\text { Chapter II: Literature Review } & 16\end{array}$

$\begin{array}{ll}\text { Occupational Therapy's Current Role } & 16\end{array}$

$\begin{array}{lr}\text { Barriers to Participation in Adaptive Sports } & 18\end{array}$

Positive Impact of Participation in Adaptive Sports 19

$\begin{array}{ll}\text { Chapter III: Methods } & 20\end{array}$

$\begin{array}{ll}\text { Participants } & 20\end{array}$

$\begin{array}{ll}\text { Materials } & 20\end{array}$

$\begin{array}{ll}\text { Design } & 21\end{array}$

$\begin{array}{ll}\text { Procedures/Timeline } & 22\end{array}$

$\begin{array}{lr}\text { Chapter IV: Results and Analysis } & 23\end{array}$

$\begin{array}{ll}\text { Analysis } & 23\end{array}$

$\begin{array}{ll}\text { Results } & 23\end{array}$ 
Chapter V: Discussion and Conclusion

Discussion

Limitations

Implications for Occupational Therapy

Future Research and program development

Conclusion

References

Appendix A. Observational Chart Example

Appendix B. Survey Questions

Appendix C. Interview Questions

Appendix D. Activity Analysis Example

Appendix E. Sports Interest Checklist

Appendix F. Intake Form

66

Appendix G. Presentation of Findings 
Improving Awareness and Access to Adaptive Sports

\section{Background}

Adaptive sports can be defined as a recreational activity that allows individuals to improve their overall quality of life through an occupation they enjoy (Aytur et al., 2018). Barriers to participation in adaptive sports programs include a lack of resources, limited programs identified, and difficulty in finding the best program to fit the athletes' needs (Lape et al., 2018). Research has identified barriers, the value of participating, and the empowerment participation in adaptive sports can provide, but more inclusive sports opportunities are needed (Aytur et al., 2018). Adaptive sports have been seen as a holistic rehabilitative care plan that helps to improve self-esteem, build self-identity, increase confidence, and provide higher life satisfaction (DiVincenzo, 2013). Occupational therapy has a focus on maximizing health, enhancing well-being, and improving quality of life through participation of occupations (American Occupational Therapy Association [AOTA], 2019). Occupational therapists can play a role in helping enhance participation in adaptive sports by looking at different programs in a holistic manner to understand the program, the athletes, the volunteers and staff, and the environment (AOTA, 2019). Occupational therapy can be a significant contributor to adaptive sports through activity analysis, adaptive equipment, and helping to better understand the impact of client factors, psychosocial factors, environment, and performance (AOTA, 2019).

There are little to no programs for smaller communities such as small towns and rural areas, which can lead to hours of travel time to play a sport (Piatt et al., 2014). A lack of programs in school systems is also apparent, which can indicate that persons with physical disabilities are not athletes, as well as take away from play with peers (Piatt et al., 2014). Occupational therapists can assess both the physical and social environment, which can include 
looking at geographic terrain and availability to individuals (AOTA, 2014). Occupational therapy may have important insight to enhance the accessibility of programs, which can help increase participation and create a more enticing location for all athletes. With more accessible programs, other aspects to the social environment can be considered including mentorship for more awareness to adaptive sports programs (Aytur et al., 2018).

Not only is there a lack of programs and awareness of programs, but location has also shown to be a barrier. Location can reduce participation through factors such as travel time, money, and emotional and physical resources (Lape et al., 2018). Frustration has been noticed with publicly funded transportation due to long wait times, inconvenience, and loss of autonomy (Lape et al., 2018). Some locations did not have the proper setup or equipment available (Lape et al., 2018). Restrooms were not always accessible, appropriate staff was not always present (e.g. medical staff), and the knowledge of what the sports needed in terms of equipment and the type of day was not always assessed (e.g. clear windy day for wind surfing) (Lape et al., 2018). Occupational therapy can utilize activity analysis to gain knowledge on what participants need in terms of accessibility, and can share this information to programs to help with increased participation.

In addition to barriers concerning program development and location, personal and environmental factors can inhibit the participation in adaptive sports including difficulty finding information about program offerings (Lape et al., 2018). Some personal factors that contribute include the disability itself, time, and lack of energy (Jaarsma, Dijkstra, Geertzen, \& Dekker, 2014). Environmental factors include a lack of sports possibilities, lack of information, and cost (Jaarsma et al., 2014). A lack of information being provided about adaptive sports from specialists has been found, including medical professionals and sports professionals (Lape et al., 
2018). Participants feel that more publications and education are needed to advise others of adaptive sports programs and the access to programs available (Lape et al., 2018). Thus, knowledge acquisition is important to understand programs that are being offered and to share this information with individuals that may benefit. With the increasing development of sports and different populations involved, participation is aspired but not obtained (Blauwet et al., 2016). Occupational therapy can play a role in understanding what the population needs as well as the equipment needed for an array of different sports. This enhanced role for occupational therapy can lead to advocacy for adaptive equipment that can be helpful, as well as advocacy for athletes to participate due to the many benefits that sports can fulfill.

Research has been completed to understand the benefits of adaptive sports such as valuing social roles, empowering individuals with disabilities, and helping participants understand their individual capacities (Aytur et al., 2018). The literature has gaps in the factors that lead to sustained participation and strategies to enhance the efficacy of adaptive sports programs (Blauwet et al., 2016). Occupational therapy can bridge this gap by providing skill sets such as activity analysis and recommendations for adaptive equipment can help provide increased participation and quality of life.

The occupational therapy practice framework defines occupation as "everyday activities that people do as individuals, in families and with communities to occupy time and bring meaning and purpose to life" (AOTA, 2014, p. S5). Adaptive sports can fall under the occupational category of leisure, which is defined as a "nonobligatory activity that is intrinsically motivated and engaged in during discretionary time, that is, time not committed to obligatory occupations such as work, self-care, or sleep" (AOTA, 1014, p. S21). Participating in adaptive sports has been shown to provide many positive benefits including finding a role, increasing 
physical well-being, creating social relationships, and mediating psychosocial impacts due to the conditions they are experiencing (Aytur et al., 2018). Delving into the history of adaptive sports can help provide insight on how adaptive sporting events began and the transitions programs have made. Dating back to 1941 during the Eastern Front of World War II, Therapeutic Physical Education (TPE) was recognized (Evseev \& Evseeva, 2016). This was a time when physical education was delivered to wounded soldiers and officers with many having physical impairments, especially spinal cord injuries (Evseev \& Evseeva, 2016). In 1960, the Summer Paralympic Games launched, and in 1976 the Winter Paralympic Games followed, but the participants that qualified were only those that had sustained a spinal cord injury (Evseev \& Evseeva, 2016). Other diagnoses were not recognized to participate, limiting the population vastly. As time went on, people with many other diagnoses joined the games, and change was beginning to happen. Engagement in adaptive sports provides an opportunity for expression of self-identity, social engagement, and improvement in skills (Aytur et al., 2018). This historical progression from applying rehabilitation to military service and spinal cord injuries to developing adaptive sports for an array of different diagnoses, shows the progress that has been made and the future possibilities for adaptive sports. But even with the progress that has been made, adaptive sports programs and resources are limited despite the fact of the numerous benefits of participation (Blauwet et al., 2016).

Many programs such as Disabled Sports USA and Anthem Foundation are charitable organizations that provide a way for individuals with disabilities a way to enhance their health and well-being through sports ("More than 900 Low Income Youth," 2017). Programs can help motivate people to get back to participating in occupations they enjoy. Not only do adaptive sports programs have health benefits, but occupational therapists can help promote the valued 
occupation of engaging in sports to guide lives in a positive direction. After injury, athletes can be fearful of returning back to sports, so encouraging a variety of different activities can be helpful to finding a role (Piatt, Bell, Rothwell, \& Wells, 2014). Sports can be a pathway used to find other interests and build confidence to succeed in other roles and meaningful occupations. Occupational therapy can help support programs and athletes as well as analyze activities to help increase participation and improve quality of life.

\section{Statement of the Problem}

There is scarce literature on occupational therapy and adaptive sports, however occupational therapy has been shown to provide benefits to participation (Aytur et al., 2018). Programs and locations in adaptive sports are not well known, which can decrease participation (Aytur et al., 2018). Programs are being advertised among friends, at support groups, and within sporting teams, but those not participating amongst these groups may not be aware (Lape et al., 2018). Increasing awareness and access to adaptive sports through advocacy, role identification, and activity analysis can provide vital information to enhance participation

\section{Purpose Statement}

The purpose of this capstone project is to evaluate the needs regarding access and awareness to adaptive sports and concerns of participants, volunteers, and others conducting adaptive sports programs to provide a better understanding of what is needed and how to bridge the gap to help sustain participation. Through activity analysis, the use of adaptive equipment, and a better understanding of what the needs and barriers are, occupational therapy can help adaptive sports programs focus on facilitating participation and educating others on how to better improve sports programs for all (De Luigi \& Cooper, 2014). 


\section{Rationale}

Adaptive sports have been shown to have a positive influence on quality of life, overall health, quality of family life, quality of social life, and individualized identity (Zabriskie, Lundberg \& Groff, 2005). Participating in sports can provide a positive impact on one's life, which can also encourage social participation in a common interest. Participation can provide a positive outlook on life by finding an identity through occupation. In the Model of Human Occupation (MOHO), occupational identity has been described as using volition, habituation, and experience to find a sense of who one is and wishes to become (Kielhofner, 2008). MOHO is a holistic approach that understands a person and how the environment can contribute to motivation, behavior, and performance (Kielhofner, 2008). This model can be correlated to the concept of occupational identity, which looks at areas such as self-efficacy, self-confidence, selfesteem, and personal motivators (Phelan \& Kinsella, 2009). MOHO aligns with concepts of occupational identity such as through evaluating volition and habituation. Volition is what motivates the individual to choose what they do and the thoughts and feelings about participating in the occupation (Kielhofner, 2008). Habituation can be described as roles, routines, and how occupation is organized into patterns that help individuals in their everyday life (Kielhofner, 2008). MOHO can be applied to adaptive sports for individuals are utilizing sports as a way to find who they are and how the sport makes them feel. Adaptations provided though a MOHO lens can help with occupational identity and competence. This identity can encourage participants to start or return to sports through adaptive sports programs and find a connection with themselves by returning to a meaningful occupation.

Occupational identity encompasses roles and relationships and how one relates to others (Christiansen, 1999). It looks at social dimensions and relationships and how they cannot only 
help with social approval to occupations, but also can help form, shape, and produce identities (Phelan \& Kinsella, 2009). Each person acquires a set of skills, knowledge, and experiences that will assume multiple roles and be displayed when participating in an occupation (Law et al., 1996). Adaptive sports can provide a team dynamic, incorporating social participation with a group that has similar interests and goals. An individual can find a role through a sporting event or through participation of sports with other colleagues. MOHO assists occupational therapists in assessing how the environment can impact occupational performance. The environment is defined as more than just the place, but includes the cultural, socioeconomic, institutional, physical, and social aspects (Law et al., 1996). It will be important to assess interests and personal causation for positive performance and a positive experience for each athlete. Roles that are found through sports can help build confidence within the individual returning to playing sports, becoming proud of who they are and becoming, and increasing confidence.

Participating in occupations such as sports can create a sense of belonging and provide a relationship between what individuals are doing to who they are becoming. Wilcock (1999) applies the concepts of doing, being, becoming, and belonging as a way to alleviate occupational dysfunction and utilize the occupational nature of people to meet their needs. Wilcock (1999) describes a balance between doing and being that allows for an individual to become whatever they are fitted to do. Doing an occupation will help create and shape that individual and provide a sense of being (Wilcock, 1999). From this concept, participating in sports will enable individuals to utilize their talents and abilities and be able to do and engage in occupation. This allows for individuals to become who they want and achieve well-being. Once participating in an occupation such as sports, individuals begin to be and become. Becoming can be described as transformation and self-actualization while still having the capacity to grow (Wilcock, 1999). 
Participation in sports can provide attributes such as confidence and well-being to pursue different occupations. Thus, bringing a sense of belonging, which increases interpersonal relationships, support, friendship, inclusion, and social interaction (Hitch, Pepin, \& Stagnitti, 2014). Sports can provide a way for participants to become active and enjoy an occupation they love, but also provide other avenues to help find a sense of belonging. Participating in sports can assist in discovering new occupations that they enjoy by understanding the things that people do, the relationship between what they do with who they are, and how occupation can provide a state of becoming (Hitch et al., 2014). Finding the relationship between participating in sports and exploring other occupations can be beneficial to better understanding the meaning to participation and all it entails (Aytur et al., 2018).

Occupational therapists can play the role of supporting individuals to return to playing a sport that they love or exploring new opportunities with the many sports available to them. Occupational therapy will not only look at the individual, but will encompass the environment, how the activity fits into their life pattern, the role that the individual will present, and the performance of the activity. From this, a sense of occupational identity can provide confidence within themselves, as well as be a motivator to engage in other activities.

Numerous programs and competitive atmospheres should be recognized and advertised so individuals can become aware and participate in the many sporting events that are being offered nationwide. With research demonstrating that adaptive sports can reduce negative emotions and increase positive psychological outcomes related to higher life satisfaction, psychological adjustment to injury, and increase quality of life, participation in adaptive sports can be a meaningful occupation to certain individuals (Prout \& Porter, 2017). With these positive 
outcomes, adaptive sports can bring many participants together to help with individual meaning as well as social identity through the use of sports.

\section{Significance of the Project}

With improved resources to access adaptive sports programs, participation can increase, benefiting individuals wanting to play sports. The future expansion of knowledge on adaptive sports can provide an outlet to those that find sports to be a meaningful occupation. Engagement in adaptive sports is a practical option for individuals with disabilities to participate and connect with the community and return back to former leisure interests (Smith \& Pei-Chun, 2017). Adaptive sports can assist individuals in taking chances and testing their individual skills as well as leadership (Kuntzler, 2013). Different levels of sports can be accomplished, but competitive sports give participants the opportunity to get their physical benefits, as well as provide a social outlet (Kuntzler, 2013). Obtaining an active lifestyle has many benefits, not only for their body, but also for social participation, finding a role, and defining their identity (Daugherty \& Yancosek, 2007). Research has shown that adolescents with physical disabilities that do not participate in activities will have a higher risk for a sedentary lifestyle (Piatt et al., 2014). With participation in sports, athletes have demonstrated a higher level of physical activity as they get older and a commitment to a sport they enjoy (Piatt et al., 2014). Adaptive sports have shown many benefits through research, so it will be valuable to understand the meaning of adaptive sports and the potential barriers to successful participation.

Occupational therapists can benefit from a better understanding of adaptive sports and programs that exist in order to help individuals return or experience sporting events that are meaningful to them. As discussed, participation in sports can have many benefits for the individual such as finding an identity and health benefits (Zabriskie, et al., 2005). Other 
important aspects can arise from participation including social engagement and support systems. Health professionals can assist in having individuals with disabilities resume previous or take on new roles, engage in physical activity, and reintegrate in to the community (Smith \& Pei-Chun, 2017). Occupational therapy can provide a way to help with adaptations and modifications. As mentioned in research, adapting can be simple but makes a significant difference to think about the individual holistically and how to help them participate (Kuntzler, 2013). Everyone is different and will have different abilities, but the goal for programs is the same: to have everyone participate (Kuntzler, 2013). Providing opportunities to participate in sports can assist in developing friendships, optimizing physical function, enhance overall well-being, and help find a sense of inclusion (Gossett \& Tingstrom, 2017). In this way, with the proper resources and information provided, participation in adaptive sports can increase leading to significant benefits to individuals.

\section{Preliminary Project Objectives}

- Observe and assess different adaptive sports camps and programs

- Perform a needs assessment to determine positive factors and potential areas of limitations in sports and programs with athletes, volunteers, and staff to better understand strengths and barriers to current programs

- Observe and perform activity analysis on different programs to break down components of a program (activity demands, environment, performance skills)

- Educate programs on findings and potential adaptive equipment or adaptations to programs 


\section{Assumptions}

Based on the research, it can be assumed that there are barriers to adaptive sports that are prohibiting athletes from participating and that people are not aware of programs to attend. These barriers would include both knowledge of programming, access to programming, and factors related to sustained participation. Sustained participation is not obtained due to varying barriers that may include personal and environmental factors (Jaarsma et al., 2014). Understanding and improving on these barriers found potentially can increase participation and enhance quality of life. It can also be assumed that participants want to utilize adaptations, modifications, and adaptive equipment when participating in programs. Participants may already be aware or own equipment needed to participate. Although some may be aware, equipment can be costly and athletes may want to participate in multiple sports making it difficult to sustain equipment (Cottingham, Vineyard, Velasco, \& Asias, 2017).

\section{Limitations}

There are several limitations that should be addressed within this project. There is a limitation to when the project is conducted and the weather conditions at the time since this project will be completed during the winter months. This can impact the observations of outdoor sports if bad weather arises and mostly winter sports will be observed due to the season. Another limitation is the individuals directly and indirectly involved in the sporting program already have knowledge on the sports and the availability of them at this program. Lastly, the sports that will be available will only be the sports that are being provided at the site.

\section{Delimitations}

Delimitations include the fact that all ages and populations can be a part of this project, all sports available can be explored, and the needs assessment of participants, volunteers, and 
staff will be analyzed to gain a better understanding of participation and occupational needs within adaptive sports and programs. With no limitation on sport or disability, the information gathered may not translate to other sports or level of abilities.

\section{Chapter II Literature Review}

The literature review section will provide a summary of existing research on occupational therapy and adaptive sports, the barriers to participating in adaptive sports and programs, and the positive impact adaptive sports can have. The literature review will assist in gathering relevant research already published, and increasing knowledge on adaptive sports and the many benefits participation can have.

\section{Occupational Therapy's Current Role}

Research has documented that sports and physical activity have an important effect on individuals with disabilities. Many research studies show how occupational therapy works with an array of different populations such as military, schools, and different sporting programs to fit the needs of athletes (Block, 2019; Gossett \& Tingstrom, 2017; Zera, 2015). Limited research has been conducted on how occupational therapy provides a role in adaptive sports programs to enhance participation and provide a meaningful occupation for those in need (DiVincenzo, 2013).

Daugherty \& Yancosek (2007) found that when working with military service members, a different kind of program needed to be developed to address the needs of the participants. Some needs identified were high paced activity, independence, and empowerment (Daugherty \& Yancosek, 2007). Through activity analysis, the occupational therapist adapted the rehabilitation to a fast paced, challenging variety of activities to better fit the goals of the athletes. An article on a winter sports clinic found that occupational therapists can play a vital role in helping to 
coordinate activities and problem solve any changes that occur in scheduling (Zera, 2015). Zera (2015) also identified that occupational therapists can utilize their skills on time management to help athletes get to each station as well as use any adaptive equipment needed for transportation or competing in events. Adaptive sports can be a means to bridge the gap between formal rehabilitation and lifelong physical activity, with occupational therapy assisting with roles, adaptations, modification, adaptive equipment, and activity modification to assist with barriers to participation (Blauwet et al., 2017).

The role of occupational therapy has also been researched within acute inpatient rehabilitation and the importance of resuming to meaningful life roles with the constraints of the environment (DiVincenzo, 2013). At a clinic in Chicago, an adaptive sports day was held every month for individuals of all different medical diagnoses to learn more about adaptive sports and recreation (DiVincenzo, 2013). The occupational therapist would help transport athletes as well as address the goals the athletes wanted to reach (DiVincenzo, 2013). Adaptive sports gave individuals the opportunity to learn about opportunities available to them and motivate participants to engage in challenging tasks, encourage them to explore meaningful occupations, and improve their quality of life (DiVincenzo, 2013). Participation shows the importance of community, and raising awareness of athletes' own abilities to increase their quality of life (Lape et al., 2018). The literature can assist with understanding how occupational therapists in different settings can provide a role in understanding patient's roles and routines and if sports is important to them. If so, tools such as the interest checklist can identify sports participants want to play, and occupational therapists can take this information and assist in creating a routine to participate. This capstone project can examine how an occupational therapist can play a role in 
adaptive sports programs utilizing their skill set of activity analysis, role identification, and adaptive equipment to better suit the needs of the participants.

\section{Barriers to Participation in Adaptive Sports}

A study done by Piatt, Bell, Rothwell, \& Wells (2014) showed that there is a lack of opportunity for adolescents with physical disabilities to participate in sporting events. Research has discovered that more programs are arising, yet are limited in urban, rural, and school communities (Piatt et al., 2014). Individuals with less opportunity showed a greater change of sedentary lifestyle, as well as other barriers that can interfere with participation such as lack of awareness of different sports available, lack of adapted equipment, and cost (Piatt, et al., 2014). Aytur et al., (2018) found barriers including travel time, discriminatory societal attitudes, misinformed providers, inaccessible facilities, limited communication, and limited staff and equipment resources. With these barriers, a lack of opportunity to participate in adaptive sports can lead to a decrease in physical activity, decrease quality of life, and a lack of self-confidence and role identification.

Although research is finding many barriers to participating with both personal and environmental factors, research has found barriers can be overcome. Lape et al. (2018) found participants overcame significant barriers, which led to physical benefits and transformative feelings in the way they viewed themselves. Some barriers participants overcame were modifications in transportation, and difficulty identifying locations of programs (Lape et al., 2018). Occupational therapy can help provide an in depth understanding of programs, what they are offering, and address barriers to participation in order to provide potential suggestions that can heighten adaptive sports programs (Daugherty \& Yancosek, 2007). Through the use of activity analysis, this capstone project can identify key components to participation in adaptive 
sports such as terrain, cost, location, and adaptive equipment necessary to participate. With this knowledge, participants will have a better understanding if the sport is appropriate to them, and programs will better be able to adapt to their population with the activity analysis provided by the occupational therapist. This can potentially eliminate barriers that have been found in previous research such as environmental limitations.

\section{Positive Impact of Participation in Adapted Sports}

Physical activity has been shown to provide many benefits to those participating in sports including a lesser chance of sedentary lifestyle and improving on one self. Participation in sports can help promote identity formation, social connections, and provide a means towards life goals (Aytur et al., 2018). There is also an expansion with technology and biomechanics, with improved wheelchairs and prostheses helping individuals find their identity and feel a part of the sport (Cooper \& De Luigi, 2014). Technology and modifications can also expand outside of sports and become re-integrated in to daily routine. Smith \& Pei-Chun (2015) found that participating in higher level competitive sports showed higher levels of re-integration back to previous social roles and activities with higher life satisfaction and quality of life. With this, sports have shown a positive impact on physical well-being, finding identity, returning back to social roles, and independence (Smith \& Pei-Chun, 2015).

Research has discovered that adaptive sports programs can empower individuals to try new sports, build friendships, identify new possibilities, and create a bond with a group to find identity (Martin, 2018). Camp Discovery is for female wheelchair users to provide an unintimidating environment for participants to be vulnerable, and embrace who they are (Martin, 2018). They participate in different sporting events such as yoga, swimming, and wheelchair basketball, and additionally have personal development activities such as attending seminars on 
dating, pregnancy, and pain management (Martin, 2018). This has shown to have participants understand more about themselves and who they are, as well as increase well-being through friendship, exploration, and finding one's identity (Martin, 2018). Through observation and interviews, this capstone project will gain insight on the significance that participation in adaptive sports has had on individuals and the benefits they noticed. The information found through observation and interviews can provide data on the importance adaptive sports can have, the benefits of participation, and how these skills can translate over to participating in other occupations that are meaningful to those participating.

\section{Chapter III Methods}

\section{Participants}

Participation in adaptive sports have shown many benefits, but a substantial number still do not participate (Lape et al., 2018). This capstone project focused on the needs of individuals directly and indirectly involved in the sporting events. This project included all participants and staff members at the Casa Colina Outdoor Adventures Program who wished to participate. The Casa Colina Outdoor Adventures Program is open to all disabilities and creates an atmosphere where individuals can experience day trips and adventures. Casa Colina included patients at the facility on trips as well as any community member interested in attending. The inclusion of all participants helped eliminate potential limiting factors that may be associated with participation in adaptive sports (Lape et al., 2018).

\section{Materials}

An observational chart was created and used to gather and write down information on different key categories including different environments, terrains, barriers, and facilitators observed at different sporting sites (See Appendix A). Different sporting sites were observed to 
understand where locations of programs were being held at, as well as the many different sports that were being played. Data for the observational chart was collected first in handwritten notes while observing the activities, and then organized and transferred to a Microsoft Word document in a chart on a laptop. A survey was created and modeled after a quality of life assessment tool to better understand participation in adaptive sports (See Appendix B). These questions were used to gain information on the sports currently being participated in, sports wished to participate in, and the barriers as to why participation is not being obtained. Surveys were completed either online or on paper and took about 10-15 minutes to complete. A semi-structured interview was used to gain a more in-depth perspective on why individuals are participating in adaptive sports programs, the barriers and facilitators noticed, and information on the impact that adaptive sports has had on roles and routines (See Appendix C). Interviews were conducted in person or over the phone, whichever was more convenient to the participant. Handwritten notes were taken during the interview with the interview lasting approximately 20-30 minutes. Notes then were typed on a laptop and analyzed in to themes. A semi-structured interview provided opportunity for participants to expand on questions and share experiences or more information deviating from the questions if needed. Interview questions were modeled after the Occupational Circumstances Assessment Interview and Rating Scale (OCAIRS). This is an assessment based off of the Model of Human Occupation and will help keep a focus on roles and routines and how adaptive sports impacts participants daily lives. All responses were held annonymous.

\section{Design}

This needs assessment used observation, surveys, and semi-structured interviews in order to gain a deeper understanding of the needs of each participant. Observations were completed at Casa Colina to better understand the many different adaptive sports programs and facilities. 
Observations have been a common method to evaluate the design and adaptations to a program (Wells et al., 2019). The observations found were helpful to better understand the different sports offered, how the program was run, the different environments utilized, and the diagnoses present. A needs assessment was used in order for participants to describe and reflect on their lived experiences through their perspective (May-West, Craig \& Wilder, 2018). Semi-structured interviews were used to understand the meaning of experiences that cannot always be observed or that occurred in the past (May-West, et al., 2018). Participants for the surveys and interviews were from the facility or Outdoor Adventures Program at Casa Colina. The surveys were analyzed to better understand participation in adaptive sports and the impact it has on individuals' daily lives. The interviews were coded to find common themes of needs and barriers to adaptive sports and reasons to why participation is obtained and the impact it has on daily roles and routines.

\section{Procedures/Timeline}

This capstone project identified needs in different adaptive sports and informed the site on potential modifications and adaptations to be more accessible. Adaptive sports programs are growing, and occupational therapy can provide a role in activity analysis to better understand how adaptive equipment, modifications, and adaptations can help provide greater participation. This capstone project was completed in 16 weeks. Observations began in December 2019, which consisted of observing different sporting events and taking handwritten notes with an observational chart for accurate data collection. These notes were then organized electronically in a chart. Surveys were administered to participants around week 6 and recruitment of participants for interviews occurred shortly after due to the time constraint on the project. Interviews were conducted from week 6 to around week 12 and completed at the convenience of 
the participants. The final step was an informational PowerPoint presentation on the findings to the staff of Casa Colina's Outdoor Adventure Program and suggestions on any modifications to the program and occurred in February 2020.

\section{Chapter IV Results \& Analysis}

\section{Analysis}

Data analysis for this capstone project was gathered through observation, results from surveys, and themes found through semi-structured interviews. Surveys were collected and analyzed to gain an understanding of participation to adaptive sports. All interviews were transcribed and thoroughly analyzed to determine common themes.

\section{Results}

After careful review and examination of the data from the surveys provided to the participants, information was gathered and discovered on the participants. Out of the 10 participants, 6 identified as male, and 4 as female. From the 10 participants, $50 \%$ have been participating in adaptive sports for 1-2 years, with the next highest percentage equating to $30 \%$ participating for 5-10 years (See Figure 1). Eighty percent of the participants participated in sports prior to injury (See Figure 2). One of the main findings from the survey consisted of the barriers to participation, with the top two responses resulting in six participants selecting "transportation" and "equipment", and four participants selecting "unaware of available programs" (See Figure 3). Another main finding from the survey was reasons to participate, with results showing the top four responses with 6 participants selecting each: previously participated, increase health and fitness, fun, and learning new skills (See Figure 4). Lastly, out of the main 
findings, all 10 participants agreed that participation in adaptive sports has helped them to participate in other activities of daily life (See Figure 5).

How long have you been participating in adaptive sports?

10 responses

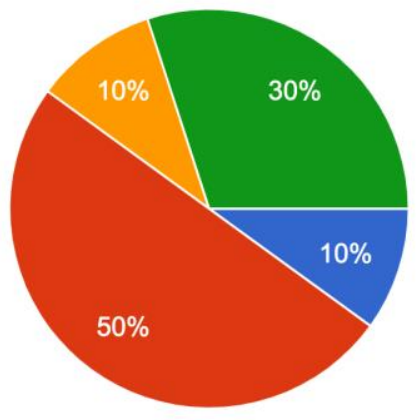

Less than 1 year

1-2 years

3-4 years

5-10 years

$10+$ years

Figure 1. This figure illustrates results from the 10 participants on the length of time participating in adaptive sports.

Did you participate in sports before your injury?

10 responses

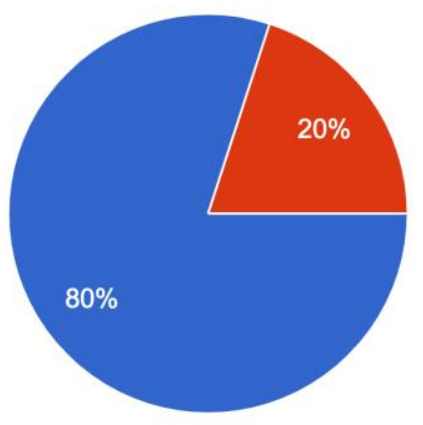

Yes

No

Figure 2. Results from 10 participants on whether participation occurred before injury. 
What barriers are in the way of your participation in adaptive sports (please select all that apply)? 10 responses

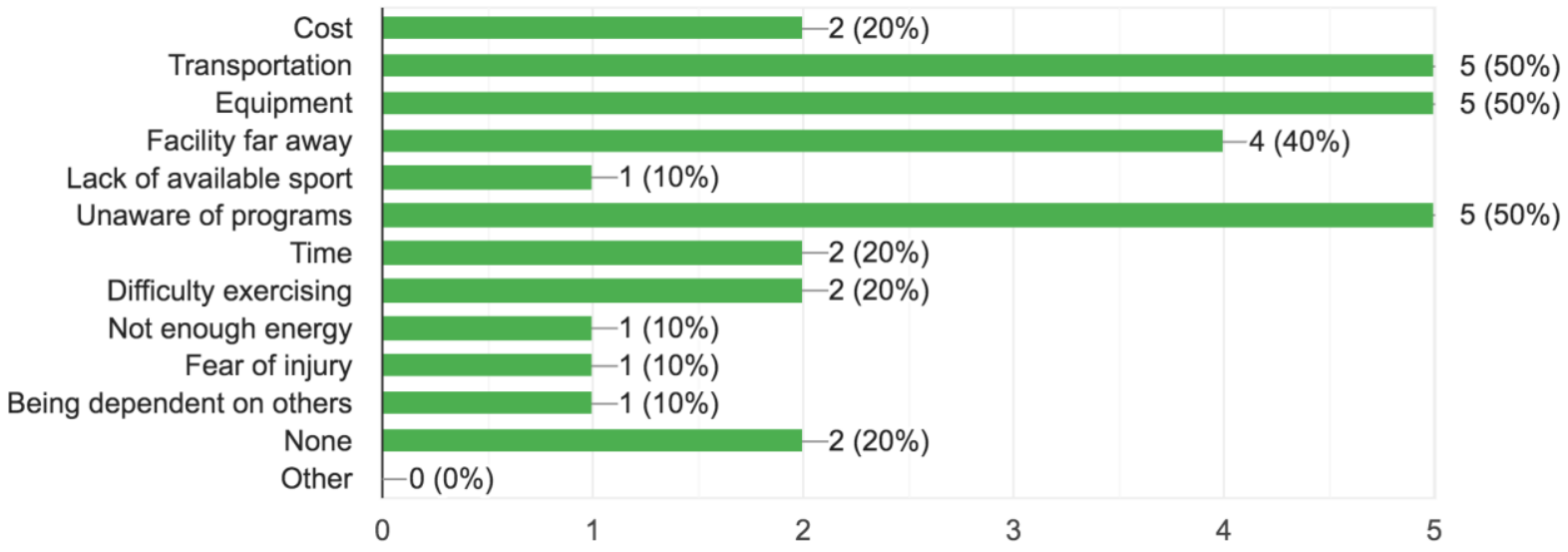

Figure 3. This graph is a summary of the 10 participants and the barriers experienced to participation in adaptive sports.

What were the reasons to participate in adaptive sports (please select all that apply)? 10 responses

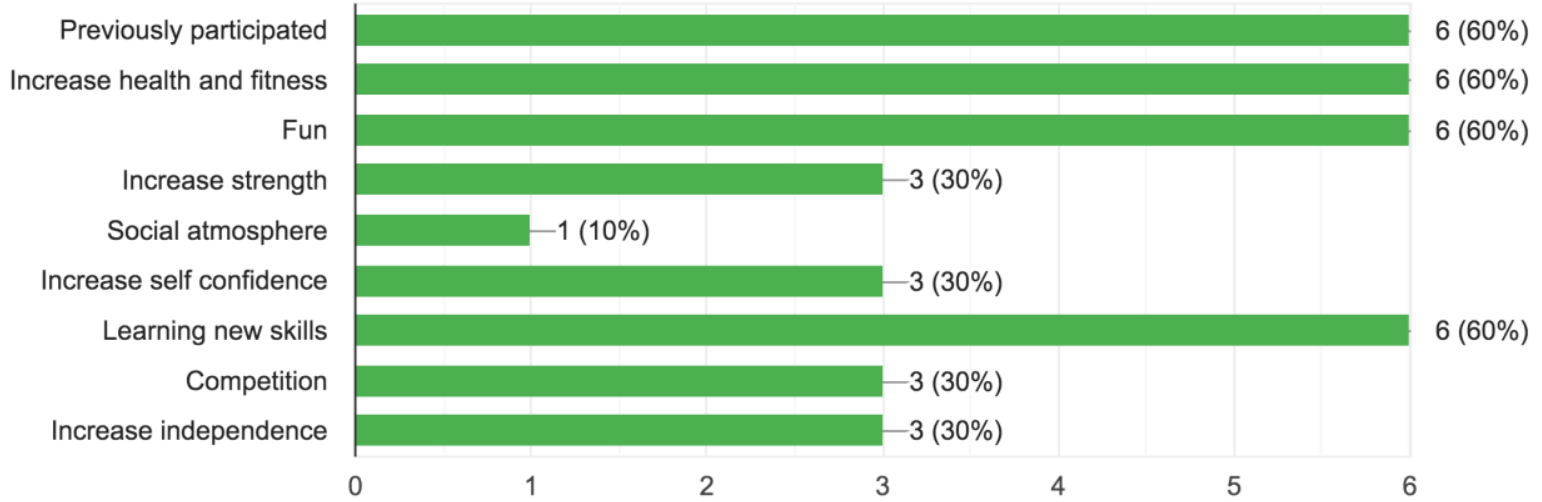

Figure 4. This chart demonstrates the 10 participants selection to facilitators to participation in adaptive sports. 
Do you think participation in adaptive sports has helped you participate in other activities? 10 responses

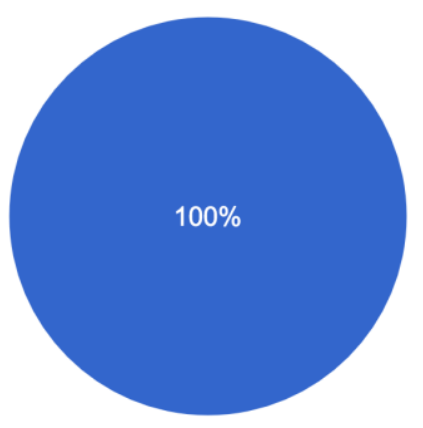

Figure 5. This chart represents the impact on the 10 participants that adaptive sports has on participating in other activities.

Through semi-structured interview responses, six common themes were identified.

Themes were categorized between barriers and facilitators (See Table 1). Common themes for barriers included transportation, cost, and lack of awareness, with themes for facilitators consisting of competition, confidence, and social interaction.

Table 1

Common Themes

\begin{tabular}{ll}
\hline Themes & Examples \\
\hline Barriers & $\bullet$ Time management and public \\
Transportation & $\begin{array}{l}\text { transportation } \\
\text { Difficulties obtaining rides from ride } \\
\text { share (Uber, Lyft) }\end{array}$ \\
& $\bullet \quad$ Relying on others \\
Cost & $\bullet$ Program Participation \\
& $\bullet$ Equipment \\
Lack of awareness & $\bullet$ Unaware of available programs near \\
& home
\end{tabular}


- Brochures or internet sites not informational

\section{Facilitators}

Competition

Confidence

Social interaction
- Wanting to improve

- Previously participated

- Motivation to continue participation

- Learning new skills grows confidence

- Confidence to perform in other activities

- Confidence in themselves

- Participate with friends

- Learn about other programs through friends

Barriers. Three main barriers were found which included transportation, cost, and lack of awareness. With more awareness and understanding to certain barriers to participation in adaptive sports, occupational therapists can assist in creating a routine with transportation, recommendations to different adaptive equipment to potentially reduce cost, and advocate to programs on questions to ask participants before arriving, and advocate to participants on questions to ask programs to better understand if that program is appropriate for them.

Transportation. Through observation and semi-structured interviews, different barriers were found including difficulty with transportation. Casa Colina provided transportation to clients with the accessible vehicles they own. Casa Colina holds many different outings throughout each month, and is open to patients at the facility as well as any community members with any disability. With the help of staff and volunteers, outings were made possible and one participant from the community stated, "I am fortunate that Casa Colina is close by and provides this opportunity with transportation or she wouldn't be able to go out and participate." To other community members, transportation was not as accessible. One patient discussed using a type of transportation that commutes many different individuals to wherever they need to go. Although 
beneficial, time management can be difficult, as one participant said, "It is difficult to know how long it will take me to arrive to my destination. I have to leave at least 2 hours in advance and even then, I have been late." Another participant spoke about being fortunate to attend this event, and that, "my mom just recently retired so hopefully I can go on more trips, but before I wasn't able to because I need to rely on others for a ride.” Each participant I was able to interview was happy and excited to be attending, but showed how difficult it can be to participate due to transportation difficulties. Furthermore, observations were made on the transfer process into different types of vehicles, and the assistance that potentially was needed. It was then better understood as to why certain vehicles were needed and the difficulty obtaining the correct transportation or vehicle was necessary, unless relying on someone else. Other factors that were related to transportation were location of programs, distance time, and travel time.

Cost. Another barrier to participation in adaptive sports is cost, especially to attend programs and for equipment. There are funding options through scholarships and grants, but these can be difficult to find and obtain (McLoughlin, Weisman Fecske, Castaneda, Gwin, \& Graber, 2017). One participant said, "I love hand cycling, but I need a new bike. My bike is not the right size and I need new wheels and more gears... it is just too expensive for me to obtain." It can also become expensive to attend many trips or continue to travel to a facility each week and pay an entry fee, "I have to choose which trips I go on because it is too expensive for me to attend them all." Casa Colina provided equipment when playing different sports, and many trips utilized facilitators for instruction and equipment. If participants want more competitive play or to play more regularly on their own, obtaining different locations or programs and providing them the proper equipment can be a helpful way to increase participation in adaptive sports. 
Information that could be provided by the program could include location and cost, to help participants plan if this program is suitable for them or not.

Lack of Awareness. Interviews indicated the lack of knowledge known on available programs and was a common theme consistently brought up. When speaking to different organizations located in Southern California, the winter months are not as popular, and more opportunities arise during the spring and summer months. Many participants reported that there was a lack of awareness of available programs and wished there was a better system to gain information on where programs are located as well as the population allowed to participate. One participant stated, "As an adult and newly diagnosed, it was difficult for me to find programs. I was unable to find any programs near my home, and ended up just asking a friend to help train me. There was a lack of information on brochures and online resources, and it would be nice to have a site online to provide information." Although adapted sports are becoming more prominent, treatment to athletes has been seen to be unequitable and less valued (McLoughlin, et al., 2017). Another participant was fortunate to have found Casa Colina to be able to participate, but stated "I have always wanted to join a dance class, but haven't because I do not know where to find one." It will be important that programs and facilities clarify key factors such as location, population attending, and adaptive equipment available to inform the public so participants know if the program is appropriate for them. Advocacy to these programs can include providing questions for programs to ask individuals before arriving in order to encourage participation and prepare different adaptations and modifications necessary for participation.

Facilitators. From the data, three main facilitators to participation in adaptive sports were found including competition, confidence, and social interaction. Occupational therapists 
can identify and understand the reasoning of participation in adaptive sports through utilizing a tool such as an intake form to better identify the appropriate sport for participation.

Competition. Many participants had previously participated in sports prior to injury, so returning back or continuing to be active was a goal for them. Multiple participants addressed the competitive aspect to playing, and it gave them motivation to want to grow in the sport and improve. For those new to a sport, many stated they wanted to learn a new skill, with one participant stating, "I really want to get the technique down. I have never played this before, but it is really fun." Through observation and the actions seen through those participating, adaptive sports portrayed a sense of empowerment. It can be unclear to participants what the sport will be like after injury, or how they will be able to perform, but once participating, a new-found occupation is shown to them along with what they are capable of doing. A participant shared, "I used to be a runner and now I enjoy an array of different sports to get my heart rate up. I enjoy competitive sports and it is nice to be able to go out and explore and see others being helpful and doing the same things I like to do."

Casa Colina provides a multitude of different sports and is always looking to add more. Some sports offered are soccer, basketball, frisbee golf, pickleball, golf, rock climbing, and even take a trip up to Big Bear, CA to go skiing. These sports rotate from week to week in order to change it up for the participants, and facilities are found nearby so the commute is not far. Grading the activity to fit the need of each participant can be a key component for growth and motivation to continue participation. Competition can be portrayed in a high-level game, or competing within oneself to improve and get better each time. Staying client-centered and goal-driven through an intake form (See Appendix F) can be a positive way to have participants continue to engage in physical activity and adaptive sports. 
Confidence. Through observation and interview responses, another common theme found was confidence. Observation showed that participants became more confident with themselves, in their abilities, and to complete other activities that may not pertain to adaptive sports. Participants gained confidence while participating in activities, such as gaining technique when skiing, or going up in difficulty level when rock climbing. One participant stated after skiing for the first time, "I was nervous at first, but it was really fun... I improved on the technique and on my last run I made it down the hill without falling." Confidence also builds when goals are attained and new ones are set, with one participant sharing, "I want to improve next time... I want to be able to go farther and increase distance a little bit each time." Furthermore, when participants get to experience participation and overcome barriers such as nervousness or being timid from something new, confidence can grow significantly and accomplishments can be made to improve quality of life. One participant was able to exceed the goal they set for themselves and has a photograph to remember the accomplishment and grow from it. Adaptive sports can be used as a way to set goals, provide motivation, and achieve personal bests and aspirations that can be applied to more than just the sport itself (McLoughlin, et al., 2017).

Social Interaction. Social interaction was a common theme among the facilitators to participation in adaptive sports. Adaptive sports can provide physical activity and fit the lifestyle of each individual while bringing a group of individuals together that have a common interest (Mulhollon \& Casey, 2016). It can provide an effective support system with significant factors in place for success and motivation (McLoughlin, et al., 2017). One participant stated on an outing, "My favorite thing about today is being able to climb with all of you today. It was fun seeing everyone being supportive and having fun.” Participating in adaptive sports can also help develop relationships, which can help provide opportunities for like individuals to meet and 
make a bond (Royse, 2019). Additionally, another participant stated, "I love meeting up with my friends on different outings and playing different sports with my friends. We talk to each other about future events to go to so we can all go together." Having a group of friends to participate with can be helpful, but also is an outlet to talk to others going through a similar experience. This can provide opportunity for friendships to be formed and go beyond sport, it can be a guide through the process of getting back to other occupations.

\section{Chapter V Discussion and Conclusion}

\section{Discussion}

The purpose of this capstone project was to evaluate the needs of the participants, gain a better understanding of adaptive sports programs, and provide education on potential modifications to programs to enhance participation. The findings from this capstone project indicated that participants experienced a lack of awareness of programs available and difficulties with transportation, but found a great opportunity through sports for competition and social engagement. These findings support other studies and literature reviews that report benefits to participation in adaptive sports such as building self-identity, increasing confidence, and providing higher life satisfaction, and barriers to participation such as lack of resources, limited programs identified, and difficulty in finding the best program to fit the athletes' needs (Aytur et al., 2018; DiVincenzo, 2013; Gossett \& Tingstrom, 2017). With the data found through this capstone project and with the support of other literature, there is a need for an increase in awareness, advocacy, and a role that occupational therapy can provide through activity analysis and role identification to help support and increase participation in adaptive sports.

Many of the interviews were conducted during travel time to and from the destination of the adaptive sport event. This provided a friendly environment to communicate about adaptive sports 
and experiences, as well as feelings before and after the event. Some benefits to interviewing during travel time were not having a constricted environment, like a classroom, an easy interaction due to typical communication in a vehicle, and the discussion could begin with the sport being played that day. Although found to be an appropriate time for interviews, data potentially could be skewed based on attending and participating in a certain sport that day. A list of interview questions was utilized to gain a deeper understanding of experiences and knowledge of adaptive sports, but interviews occasionally deviated from the questions.

More than half of the participants reported common facilitators to participating in adaptive sports which were: previously participated, fun, physical benefits, and learning new skills. Experiencing a life changing injury or illness can affect one's physical and psychosocial wellbeing and quality of life, but engaging in occupations such as adaptive sports has been seen to be an innovative strategy to help increase fitness, confidence, and life satisfaction (Blauwet et al., 2017). It will be important to understand each participant and what their goals are to provide the most appropriate sport for them to participate in, which can be completed through an interest checklist (See Appendix E). The results from this capstone project support the benefits of adaptive sports and how impactful they can be. Occupational therapists can provide a role in assisting those interested in sports to find programs, as well as utilize the skill of activity analysis to determine the skills and requirements for the activity.

It was also found that all participants reported participation in adaptive sports helped them to participate in other activities of daily life. The majority of participants reported participation has assisted in becoming more physically active, mobile, confident, happier, and healthier. Research supports the benefits of adaptive sports on increasing overall health, quality of social life, and individualized identity (Hitch, Pepin, \& Stagnitti, 2014; Zabriskie, Lundberg \& Groff, 2005). 
The use of sports can address sensory, neuromusculoskeletal, cardiovascular, and mental client factors that can be adapted and meet the patients where they are along a continuum of skill level (Daugherty \& Yancosek, 2007). Occupational therapists can combine motor and process skills for the sports, as well as activity analysis to select the appropriate sport and then provide training on how the participant can participate (Daugherty \& Yancosek, 2007). Occupational therapists can guide clients toward the highest level of independence in all areas of occupation, while considering their life roles (Daugherty \& Yancosek, 2007).

A need is present for adaptive sports programs to be available to promote physical activity, fitness, and social skills (Hayward, Fragala-PinkHam, Johnson, \& Torres, 2016). Health professionals can design, implement, and evaluate adaptive sports programs to help promote health and fitness in participants with physical impairments and functional limitations (Hayward, et al., 2016). This capstone project showed the barriers and facilitators to adaptive sports and that occupational therapists can play a role in increasing awareness and access. This can be addressed through an interest checklist to potential participants to bring awareness to sports, as well as questions to programs to ask participants so they are more aware of what the program consists of. From the findings of this capstone project and previous research, it will be important to advocate, educate, and increase awareness to adaptive sports and available programs. There is limited research on the effectiveness of adaptive sports programs, but benefits have been shown regarding participation in adaptive sports. Further research can provide knowledge on increasing awareness such as questions programs can communicate to potential participants on what is provided through their program as well as advocacy to participants on available sports and factors the sport consists of such as body mechanics, cognitive awareness needed, and 
environmental factors. Future research can also assess the impact sports have on daily life, and the effectiveness of adaptive sports programs.

With the circumstances of a pandemic currently occurring, it is difficult to contact sports programs, with many programs cancelling events for safety. In the future, programs will be contacted to inform them on the intake form created in order to assist with gathering information to provide the best sports and programs for each participant. The modified interest list can also be provided to programs and Casa Colina as a way to identify which sports each participant is interested in. This can be a useful tool to best understand what the participant is wanting and can better prepare programs or therapists on activities to provide them. Future collaboration between programs and occupational therapists can be used to develop sites through activity analysis and role identification. Role identification was addressed during the interviews with questions such as, "Have adaptive sports helped you find a role in your daily routine?". Through activity analysis, a list of required skills was attained that can potentially help prepare athletes on the sport itself as well as the role they will be taking on as they participate. In the future, a tool such as the intake form can assist in identifying roles the participant is looking for and interests and values that can assist the occupational therapist on providing the appropriate activities to fit the roles they are interested in pursuing.

\section{Limitations}

There were several limitations in this capstone project. One limitation was a small sample size and limited amounts of participants due to transportation and weekday events during the day limiting community members from attending. Transportation was provided for every outing, allowing only a limited number of participants that could attend, especially with needed staff and 
volunteers. No specific inclusion was needed to participate in this capstone project, but limited diagnoses was seen due to types of disabilities in this particular setting at Casa Colina.

Additionally, outings occurred during the day making it difficult for community members to be able to attend if they work or rely on others for a ride. Due to these limitations, a wide range of participants was not attained and responses are correlated only to Casa Colina and the adaptive sports program they provide.

Lastly, subjective data collection stemmed from handwritten notes during observation and semi-structured interviews leading to a limitation. The semi-structured interviews were not recorded and a more in-depth review of the interviews could have been analyzed with continual review and analysis of recordings. Observations also varied depending on the day and the number of participants attending or the type of diagnoses present. Different observations could potentially have been made with a wider array of diagnoses to better understand mobility, barriers, and other observations or quotes to provide more detail to this capstone project.

\section{Implication for Occupational Therapy}

This capstone project assessed the barriers and facilitators to participation in adaptive sports and examined ways of improving access and awareness to help increase participation. There was sparse research found on adaptive sports and occupational therapy, so the objective of this capstone project was to observe, understand, and educate others on adaptive sports with an occupational therapy lens. Research has found that participation in adaptive sports can be beneficial in many ways including finding roles, creating routine, developing social relationships, and increasing physical well-being (Aytur et al., 2018). With the positive impact adaptive sports has shown, occupational therapists can provide a role in helping understand and 
increase participation through activity analysis, interest exploration, role identification, and advocacy.

Role identification has been shown to be a positive aspect to participation in adaptive sports (Aytur et al., 2018). Not only can participation in adaptive sports provide an opportunity to find a role within themselves in their everyday lifestyle, it also can provide a role on a team such as an athlete role, teammate role, friend role, and a social role (Aytur et al., 2018). In this capstone project, roles were discussed during interviews and found how important sports played in their everyday roles such a recreator role by exploring many different sports and becoming more confident in completing everyday tasks, a leadership role not only on a team but also taking control of their own lifestyle, and a social role from meeting new people and creating friendships. Occupational therapists can use tools such as a sports interest checklist and an interest form to identify roles that participants want to be a part of. In the future, these can be helpful to provide to programs in order to assist in matching the participant to the most appropriate sport.

Assessing physical and social environments is included within the scope of occupational therapy and can be essential to increasing participation (AOTA, 2014). Occupational therapists can evaluate terrains and accessibility to different programs, helping better understand how participants can reach the destination and participate fully. Having a better understanding can also provide useful information to the necessary adaptive equipment needed, the type of population that can attend, and the requirements needed for participation. This information can be provided to programs to better understand dynamics to the program to be the most accessible to all. Additionally, with a better understanding of adaptive sports programs, advocacy can be provided. Occupational therapists can advocate to different programs on specific questions they 
may want to ask participants before they arrive or provide insight on necessary information that should be given to participants prior to arriving. Interventions on self-advocacy can also be provided to participants looking to participate by assisting in developing a list of questions to ask programs and educating on how to advocate for themselves on what they need.

\section{Future Research and Program Development}

Future research studies and projects could include a larger sample size and incorporate participants from multiple programs and disabilities to help generalize the findings. This capstone project was mostly from one facility and included only a few different diagnoses. Additionally, communicating and discussing with program staff on the inclusion criteria and necessary information they need from participants can provide further insight to occupational therapists and be incorporated when discussing adaptive sports with interested participants. Participants also discussed that there is a lack of awareness of available programs as well as difficulties finding information online. The research shows a level of frustration due to transportation, location, and resources (Lape et al., 2018). Future studies and projects can focus on developing a site online to provide necessary information on different programs, locations, and the sports included. Future studies can also look in to advocating for a recognition of barriers that may inhibit participation and on information that should be provided in brochures or online resources to increase participation. In addition, future studies can explore the impact that adaptive sports have and the effectiveness on obtaining other occupations such as employment (Lastuka \& Cottingham, 2016). It was also shown through the results of the capstone project that participants who were involved in sports or a program felt it had a positive impact on completing daily activities. Lastly, future research can examine the levels of competition within each sport to better suit the needs of the athletes and their current competitive level. Participating in an 
appropriate level of competition can assist in sustained interest in a sport or provide a suitable level to match the skills of the participant.

\section{Conclusion}

Adaptive sports are becoming more popular and can assist in finding roles, increasing self-efficacy, empowering individuals, and developing friendships (Aytur et al., 2018). With the many benefits that participation in adaptive sports can provide, it will be important for those wishing to participate to know about programs that are available and what sports are provided. The purpose of this capstone project was to evaluate the needs to participation and understand how to bridge the gap to sustain participation. Several barriers and facilitators were found including difficulty with transportation, locating accessible programs, building friendships, and increasing freedom. Addressing these factors may potentially assist in increasing participation and be a guide to decreasing barriers to adaptive sports programs. Findings supported the literature that there is a lack of awareness to adaptive sports programs, but participation is beneficial and desired (Blauwet et al., 2016). This capstone project provided information in the role that occupational therapy can play to adaptive sports and participation, and the importance of increasing access and awareness for sustained participation. 


\section{References}

American Occupational Therapy Association. (2014). Occupational therapy practice framework: Domain and process (3rd ed.). American Journal of Occupational Therapy, 68(Suppl. 1), S1-S48. Retrieved from http://www.doi.org/10.5014/ajot.2014.682006

American Occupational Therapy Association. (2019). AOTA unveils vision 2025. Retrieved from https://www.aota.org/AboutAOTA/vision-2025.aspx

Aytur, S., Craig, P. J., Frye, M., Bonica, M., Rainer, S., Hapke, L., \& McGilvray, M. (2018). Through the lens of a camera: Exploring the meaning of competitive sport participation among youth athletes with disabilities. Therapeutic Recreation Journal, 52(2), 95-125. Retrieved from http://prxusa.lirn.net/login?url=http://search.ebscohost.com/login.aspx?direct=true $\& d b=s 3 h \& A N=$ $\underline{130206268 \& \text { site }=\text { eds-live }}$

Blauwet, C. A., Yang, H. Y., Cruz, S. A., Collins, J. E., Smith, K. C., Losina, E., \& Katz, J. N. (2016). Original research: Functional and environmental factors are associated with sustained participation in adaptive sports. $P M \& R$. Retrieved from https://doi-org.prxusa.lirn.net/10.1016/j.pmrj.2016.10.015

Block, M.E. (2019). University adaptive sports programs growing. Palaestra, 33(1), 4. Retrieved from http://search.ebscohost.com/login.aspx?direct=true\&db=ccm\&AN=134903536\&site=eds $\underline{\text {-live }}$

Christiansen CH. (1999). Defining lives: occupation as identity: an essay on competence, coherence, and the creation of meaning. American Journal of Occupational Therapy, 53(6), 547-558. Retrieved from 
http://www.search.ebscohost.com/login.aspx?direct=true\&db=ccm\&AN=107080973\&sit $\underline{\mathrm{e}=\mathrm{eds}-\text { live }}$

Cooper, R. A., \& De Luigi, A. J. (2014). Original research: Adaptive sports technology and biomechanics: Wheelchairs. $P M \& R, 6$ (Supplement), S31-S39. Retrieved from https://www.doi-org.prx-usa.lirn.net/10.1016/j.pmrj.2014.05.020

Cottingham, M., Vineyard, A., Velasco, F., \& Asias, B. (2017). Meeting expenses of wheelchair rugby: Strategies employed to procure funding and promotion by teams and players. Palaestra, 31(1), 16-22. Retrieved from http://www.prxusa.lirn.net/login?url=http://search.ebscohost.com/login.aspx?direct=true \&db=ccm\&AN $=122226873 \&$ site $=$ eds-live

Daugherty S., \& Yancosek, K. (2007). Sports as occupation: Walter Reed Army Medical Center's adaptive sports programs. OT Practice, 12(8), 13-16. Retrieved from http:/www./prxusa.lirn.net/login?url=http://search.ebscohost.com/login.aspx?direct=true \&db=ccm\&AN $=106127105 \&$ site $=$ eds-live

De Luigi, A. J., \& Cooper, R. A. (2014). Original research: Adaptive sports technology and biomechanics: Prosthetics. PM\&R,6(Supplement), S40-S57. Retrieved from https://www.doiorg.prxusa.lirn.net/10.1016/j.pmrj.2014.06.011

DiVincenzo, K. (2013). Participating in adaptive sports and recreation during acute inpatient rehabilitation. OT Practice, 18(14), 19-21. Retrieved from http://www.prxusa.lirn.net/login?url=http://search.ebscohost.com/login.aspx?direct=true $\underline{\& \mathrm{db}=\mathrm{ccm} \& \mathrm{AN}=107940988 \& \text { site }=\text { eds-live }}$ 
Evseev, S. P., \& Evseeva, O. E. (2016). Adaptive physical education: Mission, history and modern situation. Teoria I Praktika Fiziceskoj Kul'tury, 10, 1-5. Retrieved from http://www.prxusa.lirn.net/login?url=http://search.ebscohost.com/login.aspx?direct=true $\underline{\& \mathrm{db}=\mathrm{s} 3 \mathrm{~h} \& \mathrm{AN}=119263131 \& \text { site }=\text { eds-live }}$

Gossett, K., \& Tingstrom, C. A. (2017). Community-based adaptive recreation: Using an indoor water park for adapted kayaking. Palaestra, 31(4), 31-34. Retrieved from http://www.prxusa.lirn.net/login?url=http://search.ebscohost.com/login.aspx?direct=true $\& \mathrm{db}=\mathrm{ccm} \& \mathrm{AN}=126273857 \&$ site $=$ eds-live

Hayward, L. M., Fragala-PinkHam, M., Johnson, K., \& Torres, A. (2016). A community-based, adaptive soccer program for children with autism: Design, implementation, and evaluation. Palaestra, 4, 44. Retrieved from http://www.search.ebscohost.com/login.aspx?direct=true \&db=s3h\&AN=120591179\&site =eds-live.

Hitch, D., Pépin, G., \& Stagnitti, K. (2014). In the footsteps of Wilcock, part one: The evolution of doing, being, becoming, and belonging. Occupational Therapy in Health Care, 28(3), 231-246. Retrieved from http://www.search.ebscohost.com/login.aspx?direct=true \&db=s3h\&AN=96838518\&site =eds-live

Jaarsma, E. A., Dijkstra, P. U., Geertzen, J. H. B., \& Dekker, R. (2014). Barriers to and facilitators of sports participation for people with physical disabilities: A systematic review. Scandinavian Journal of Medicine \& Science in Sports, 24(6), 871-881. Retrieved from http://www.prxusa.lirn.net/login?url=http://search.ebscohost.com/l ogin.aspx?direct $=$ true $\& \mathrm{db}=\mathrm{s} 3 \mathrm{~h} \& \mathrm{AN}=99707865 \&$ site $=\mathrm{eds}-$ live 
Kielhofner, G. (2008). Model of human occupation: Theory and application (4 ${ }^{\text {th }}$ ed.). Philadelphia, PA: Lippincott, Williams and Wilkins.

Kuntzler, P.M. (2013). Lessons from adapted sports. Exceptional Parent, 43(5), 49-51. Retrieved from http://www.prxusa.lirn.net/login?url=http://search.ebscohost.com/login.aspx?direct=true $\& \mathrm{db}=\mathrm{ccm} \& \mathrm{AN}=104030570 \&$ site $=$ eds-live

Lape, E. C., Katz, J. N., Losina, E., Kerman, H. M., Gedman, M. A., \& Blauwet, C. A. (2018). Original research: Participant-reported benefits of involvement in an adaptive sports program: A qualitative study. $P M \& R, 10,507-515$. Retrieved from https://www.doiorg.prxusa.lirn.net/1 0.1016/j.pmrj.2017.10.008

Law, M., Cooper, B., Strong, S., Steward, D., Rigby, P., \& Letts, L. (1996). The PersonEnvironment-Occupation Model: A Transactive Approach to Occupational Performance. Canadian Journal of Occupational Therapy (Vol. 63, pp. 9-23). Retrieved from http://www.search.ebscohost.com/login.aspx?direct=true\&db=eric\&AN=EJ530261\&site =eds-live

Lastuka, A., \& Cottingham, M. (2016). The effect of adaptive sports on employment among people with disabilities. Disability and Rehabilitation, 38(8), 742-748. Retrieved from http://www.doi-org.prx-usa.lirn.net/10.3109/09638288.2015.1059497

Martin, B. (2018). Filled with confidence: Camp Discovery is empowering female wheelchair users to try new sports while building lifelong friendships. Sports 'n Spokes Magazine, 44(6), 36-41. Retrieved from 
http://www.search.ebscohost.com/login.aspx?direct=true \&db=s3h\&AN=132819785\&site

=eds-live

May-West, E. M., Craig, P. J., \& Wilder, A. (2018). The meaning of cross-country skiing for persons with significant visual impairment: A phenomenological study. Therapeutic Recreation Journal, 52(4), 349-373. Retrieved from http://www.search.ebscohost.com/login.aspx?direct=true \&db=s3h\&AN=132850322\&site =eds-live

McLoughlin, G., Weisman Fecske, C., Castaneda, Y., Gwin, C., \& Graber, K. (2017). Sport participation for elite athletes with physical disabilities: Motivations, barriers, and facilitators. Adapted Physical Activity Quarterly, 34(4), 421-441. http://www.search.ebscohost.com/login.aspx?direct=true \&db=s3h\&AN=125851463\&site =eds-live.

More than 900 low-income youth, wounded warfighters and adults with disabilities benefit from access to adaptive sports. (2017). GlobeNewswire. Retrieved from http://www.prxusa.lirn.net/login?url=http://search.ebscohost.com/login.aspx?direct=true\&db=edsggo\&A $\underline{\mathrm{N}=\text { edsgcl.480391757\&site }=\text { eds-live }}$

Mulhollon,S.,\& Casey, J. (2016). Adaptive sports and equipment for Veterans with spinals cord injuries: Community partnerships are key to a year-round adapted sports programs for Milwaukee Veterans. Palaestra, 30(4), 20-24.

http://www.search.ebscohost.com/login.aspx?direct=true\&db=ccm\&AN=120591175\&sit $\underline{\mathrm{e}=\mathrm{eds}-\text { live. }}$.

Phelan, S \& Kinsella, E.A. (2009). Occupational identity: Engaging socio-cultural perspectives. Journal of Occupational Science, 16(2), 85-91. doi:10.1080/14427591.2009.9686647. 
Piatt, J., Bell, S. A., Rothwell, E., \& Wells, M. S. (2014). Want sport but can’t find a team. Palaestra, 28(4), 33-36. Retrieved from http://www.prxusa.lirn.net/login?url=http://search.ebscohost.com/login.aspx?direct=true $\underline{\& \mathrm{db}=\mathrm{ccm} \& \mathrm{AN}=103867555 \& \text { site }=\text { eds-live }}$

Prout, B., \& Porter, H. R. (2017). Psychosocial outcomes of participation in adaptive sports for adults with spinal cord injuries: A systematic review of the literature. American Journal of Recreation Therapy, 16(1), 39-47. Retrieved from https://www.doiorg.prxusa.lirn.net/10.5055/ajrt.2017.0126

Royse, D. (2019). Broadening horizons: The junior adaptive sports camp in San Diego offers younger wheelchair athletes chances to not only play sports but to create independence. Sports 'n Spokes Magazine, 45(4), 26-31. http://www.search.ebscohost.com/login.aspx?direct=true\&db=s3h\&AN=137637104\&site =eds-live.

Smith, K., \& Pei-Chun, Hsieh. (2017). Sports participation and re-integration of persons with spinal cord injury. Therapeutic Recreation Journal, (1), 75-80. Retrieved from https://www.doi-org.prx-usa.lirn.net/10.18666/TRJ-2017-V51-I1-7890

Wells, H., Duffy, L., Nance, M., Flemming, L., Stone, G.A., Townsend, J., \& Stevenson, S.L. (2019). Does culture matter? An exploratory study of culture in the implementation of an adaptive sports progam. Therapeutic Recreation Journal, 53(3), 224-243. Retrieved from http://www.doi.org/10.18666/TRJ-2019-V53-I3-9684

Willcock, A. (1999). Reflections on doing, being, and becoming. Australian Occupational Therapy Journal, 46(1), 1-11. Retrieved from 
http://www.search.ebscohost.com/login.aspx?direct=true\&db=edsgao\&AN=edsgcl.20072 $\underline{9675 \& \text { site }=\text { eds-live }}$

Zabriskie RB, Lundberg NR, \& Groff DG. (2005). Quality of life and identity: The benefits of a community-based therapeutic recreation and adaptive sports program. Therapeutic Recreation Journal, 39(3), 176-191. Retrieved from http://www.prxusa.lirn.net/login?url=http://search.ebscohost.com/login.aspx?direct=true\&db=ccm\&AN $=106412298 \&$ site $=$ eds-live

Zera, S. (2015). National disabled veterans winter sports clinic. Communique, (2), 1-11.

Retrieved from http://www.prxusa.lirn.net/login?url=http://search.ebscohost.com/login.aspx?direct=true $\underline{\& d b=c c m \& A N=124286106 \& \text { site }=\text { eds-live }}$ 


\section{Appendix A}

Observational Chart Example

\begin{tabular}{|c|c|c|c|c|c|c|}
\hline Date & $\begin{array}{c}\text { Location/ } \\
\text { sporting } \\
\text { event }\end{array}$ & $\begin{array}{c}\text { Environment/ } \\
\text { Terrain }\end{array}$ & Barriers & Facilitators & $\begin{array}{c}\text { Access } \\
\text { points }\end{array}$ & Notes \\
\hline $12 / 2$ & $\begin{array}{l}\text { Cal Poly } \\
\text { Pomona } \\
\text { Billiards }\end{array}$ & $\begin{array}{l}\text { Sidewalk/concrete, } \\
\text { Accessible ramps }\end{array}$ & $\begin{array}{l}\text { Long walk } \\
\text { from } \\
\text { parking lot, } \\
\text { no break } \\
\text { areas }\end{array}$ & Ramps & & $\begin{array}{l}\text { Transfers in and } \\
\text { out of vans }\end{array}$ \\
\hline $12 / 5$ & $\begin{array}{l}\text { Thompson } \\
\text { Creek } \\
\text { Hiking } \\
\text { Trail }\end{array}$ & $\begin{array}{l}\text { Paved pathway } \\
\text { with optional dirt } \\
\text { path }\end{array}$ & $\begin{array}{l}\text { Sidewalk } \\
\text { leans to the } \\
\text { left } \\
\text { (difficult for } \\
\text { wheelchair), } \\
\text { parking far, } \\
\text { not a lot of } \\
\text { benches in } \\
\text { the } \\
\text { beginning } \\
\text { of the hike }\end{array}$ & $\begin{array}{l}\text { Accessible } \\
\text { through sidewalk } \\
\text { entries }\end{array}$ & & $\begin{array}{l}\text { Having sidewalk } \\
\text { and dirt option a } \\
\text { good facilitator, } \\
\text { nice park area to } \\
\text { rest if needed with } \\
\text { benches, } \\
\text { restrooms, and } \\
\text { water }\end{array}$ \\
\hline $12 / 6$ & $\begin{array}{l}\text { Horseback } \\
\text { Riding }\end{array}$ & $\begin{array}{l}\text { Dirt- recently } \\
\text { added gravel so } \\
\text { not as muddy and } \\
\text { flooding }\end{array}$ & $\begin{array}{l}\text { Transfer on } \\
\text { to horse can } \\
\text { be difficult, } \\
\text { can be } \\
\text { nerve } \\
\text { wracking }\end{array}$ & $\begin{array}{l}\text { Ramp to get on } \\
\text { and off of horse, } \\
\text { different size } \\
\text { horses, different } \\
\text { saddles }\end{array}$ & $\begin{array}{l}\text { Went right } \\
\text { through } \\
\text { gate to get } \\
\text { close to } \\
\text { horses }\end{array}$ & $\begin{array}{l}\text { Always wear } \\
\text { helmet, always } \\
\text { have side walkers, } \\
\text { horses good } \\
\text { because same gait } \\
\text { pattern as humans } \\
\text { "I was nervous at } \\
\text { first but as time } \\
\text { went on I got the } \\
\text { hang of it"- first } \\
\text { time rider } \\
\text { Use of facilitator } \\
\text { to instruct and } \\
\text { provide activities } \\
\text { while riding }\end{array}$ \\
\hline
\end{tabular}




\begin{tabular}{|c|c|c|c|c|c|c|}
\hline $12 / 6$ & $\begin{array}{l}\text { Frisbee } \\
\text { golf }\end{array}$ & $\begin{array}{l}\text { Grass with } \\
\text { minimal sidewalk, } \\
\text { concrete square to } \\
\text { stand on to start } \\
\text { game }\end{array}$ & $\begin{array}{l}\text { Difficult } \\
\text { moving } \\
\text { around on } \\
\text { grass } \\
\text { especially } \\
\text { in } \\
\text { wheelchair, } \\
\text { outdoor } \\
\text { sport so } \\
\text { weather can } \\
\text { be barrier }\end{array}$ & $\begin{array}{l}\text { Group oriented, } \\
\text { team support, } \\
\text { communication } \\
\text { between } \\
\text { participants }\end{array}$ & $\begin{array}{l}\text { Difficult } \\
\text { to access } \\
\text { if trouble } \\
\text { moving on } \\
\text { grass }\end{array}$ & $\begin{array}{l}\text { Many locations to } \\
\text { play } \\
\text { Many components } \\
\text { to take in to } \\
\text { consideration } \\
\text { when playing, i.e. } \\
\text { body mechanics, } \\
\text { balance, vision }\end{array}$ \\
\hline $12 / 9$ & $\begin{array}{l}\text { Indoor } \\
\text { soccer }\end{array}$ & $\begin{array}{l}\text { Turf with step to } \\
\text { get inside arena, } \\
\text { wheelchairs not } \\
\text { accessible }\end{array}$ & $\begin{array}{l}\text { Not } \\
\text { wheelchair } \\
\text { accessible, } \\
\text { turf was } \\
\text { tough to } \\
\text { move on, } \\
\text { shoes got } \\
\text { "caught" in } \\
\text { turf making } \\
\text { it dangerous }\end{array}$ & $\begin{array}{l}\text { Competition, } \\
\text { communication, } \\
\text { following rules }\end{array}$ & $\begin{array}{l}\text { Close } \\
\text { parking } \\
\text { with no } \\
\text { stairs } \\
\text { besides } \\
\text { entering } \\
\text { field }\end{array}$ & $\begin{array}{l}\text { "I don't know a } \\
\text { lot about soccer } \\
\text { but I'm here to } \\
\text { just have fun" } \\
\text { Favorite part of } \\
\text { activity- "getting } \\
\text { outside of } \\
\text { facility", } \\
\text { "competition" }\end{array}$ \\
\hline $\begin{array}{l}\text { 12/12- } \\
\text { TBI } \\
12 / 17- \\
\text { SCI }\end{array}$ & $\begin{array}{l}\text { Bonelli } \\
\text { Park } \\
\text { Hiking }\end{array}$ & $\begin{array}{l}\text { Cement and some } \\
\text { dirt trail, hill, tree } \\
\text { roots exiting out } \\
\text { of cement }\end{array}$ & $\begin{array}{l}\text { Hills can be } \\
\text { difficult and } \\
\text { tiring }\end{array}$ & $\begin{array}{l}\text { Sidewalk/cement, } \\
\text { better area for } \\
\text { wheelchairs }\end{array}$ & $\begin{array}{l}\text { Parking } \\
\text { right next } \\
\text { to trail }\end{array}$ & $\begin{array}{l}\text { Spatial awareness } \\
\text { necessary for } \\
\text { other people, } \\
\text { dogs, and bumps } \\
\text { in the road, path } \\
\text { taken there is a } \\
\text { cross walk so need } \\
\text { to watch for cars }\end{array}$ \\
\hline $12 / 13$ & Pickleball & $\begin{array}{l}\text { Cement court, } \\
\text { lines for out of } \\
\text { bounds and inside } \\
\text { box, played at } \\
\text { Casa Colina }\end{array}$ & $\begin{array}{l}\text { Need a net } \\
\text { and a court, } \\
\text { rackets, ball }\end{array}$ & $\begin{array}{l}\text { Not as big of a } \\
\text { court as tennis, } \\
\text { combination } \\
\text { sport of tennis, } \\
\text { badminton, and } \\
\text { ping pong, bigger } \\
\text { paddle than ping } \\
\text { pong, can use } \\
\text { different types of } \\
\text { balls (whiffle } \\
\text { ball, tennis ball) }\end{array}$ & $\begin{array}{l}\text { Courts are } \\
\text { available } \\
\text { to play at } \\
\text { or can } \\
\text { adapt and } \\
\text { set up if } \\
\text { have } \\
\text { proper } \\
\text { equipment }\end{array}$ & $\begin{array}{l}\text { Can work on hand } \\
\text { eye coordination, } \\
\text { cognition to keep } \\
\text { track of score and } \\
\text { who is serving, } \\
\text { balance, lateral } \\
\text { movements, } \\
\text { reaction time }\end{array}$ \\
\hline
\end{tabular}

\begin{tabular}{|l|l|l|l|l|l|l|}
\hline $12 / 17$ & basketball & $\begin{array}{l}\text { Court at casa } \\
\text { Colina, small court } \\
\text { with grass behind, } \\
\text { court is concrete }\end{array}$ & $\begin{array}{l}\text { Spatial } \\
\text { awareness } \\
\text { to maintain } \\
\text { balance } \\
\text { from }\end{array}$ & $\begin{array}{l}\text { Outdoors, can } \\
\text { adapt to skill } \\
\text { level fairly } \\
\text { easily, can } \\
\text { participate in }\end{array}$ & & $\begin{array}{l}\text { Best if can } \\
\text { separate in to } \\
\text { levels of } \\
\text { competition }\end{array}$ \\
\hline
\end{tabular}




\begin{tabular}{|c|c|c|c|c|c|}
\hline & & & $\begin{array}{l}\text { concrete to } \\
\text { grass }\end{array}$ & $\begin{array}{l}\text { wheelchair, do } \\
\text { not need to } \\
\text { transport if play } \\
\text { at Casa }\end{array}$ & $\begin{array}{l}\text { Dependent on } \\
\text { basketball } \\
\text { (inflated, } \\
\text { deflated) } \\
\text { Does not need to } \\
\text { strictly be } \\
\text { shooting, can play } \\
\text { passing games, } \\
\text { etc. }\end{array}$ \\
\hline $\begin{array}{l}1 / 21 \\
2 / 4\end{array}$ & $\begin{array}{l}\text { Big Bear } \\
\text { Ski Trip }\end{array}$ & $\begin{array}{l}\text { Windy road to get } \\
\text { to ski trip, slippery } \\
\text { on snow, steep } \\
\text { ramp to access } \\
\text { building and } \\
\text { getting to the snow }\end{array}$ & $\begin{array}{l}\text { Hill to get } \\
\text { up to start } \\
\text { skiing, } \\
\text { bathroom } \\
\text { down } \\
\text { below, not } \\
\text { all places } \\
\text { have } \\
\text { necessary } \\
\text { equipment }\end{array}$ & $\begin{array}{l}\text { Use facilitators } \\
\text { (USARC) to take } \\
\text { patients skiing, } \\
\text { have monoski, } \\
\text { biski, dualski for } \\
\text { pateints, skiis are } \\
\text { low to the } \\
\text { ground for easier } \\
\text { transfer if in } \\
\text { wheelchair }\end{array}$ & $\begin{array}{l}\text { Different skiis } \\
\text { depending on skill } \\
\text { level, need good } \\
\text { balance and core } \\
\text { strength } \\
\text { (Especially on } \\
\text { monoski), patient } \\
\text { stated thrilling } \\
\text { and fun } \\
\text { Refer to activity } \\
\text { analysis for more } \\
\text { detail }\end{array}$ \\
\hline $1 / 17$ & Sailing & $\begin{array}{l}\text { Outdoors, steep } \\
\text { ramp to get down } \\
\text { to boats, dock with } \\
\text { wood plates }\end{array}$ & $\begin{array}{l}\text { Transfer on } \\
\text { to boat can } \\
\text { be difficult, } \\
\text { weather can } \\
\text { be } \\
\text { prohibiting- } \\
\text { very } \\
\text { dependent } \\
\text { on the wind }\end{array}$ & $\begin{array}{l}\text { Relaxing, } \\
\text { outdoors in } \\
\text { different } \\
\text { environment, } \\
\text { wheelchair } \\
\text { accessible }\end{array}$ & $\begin{array}{l}\text { Patients in my } \\
\text { boat stated that } \\
\text { they enjoyed it } \\
\text { and one patient } \\
\text { was in the navy so } \\
\text { brought back } \\
\text { memories of past, } \\
\text { stated it was } \\
\text { relaxing and a } \\
\text { good day out }\end{array}$ \\
\hline $2 / 8$ & $\begin{array}{l}\text { Hand } \\
\text { cycling }\end{array}$ & $\begin{array}{l}\text { Outdoors by the } \\
\text { beach, windy, sand }\end{array}$ & $\begin{array}{l}\text { Sand can be } \\
\text { difficult to } \\
\text { move in, } \\
\text { bathroom } \\
\text { location far } \\
\text { away }\end{array}$ & $\begin{array}{l}\text { Used facilitator } \\
\text { RAMP to } \\
\text { provide bikes, } \\
\text { had volunteers } \\
\text { come to ride } \\
\text { alongside } \\
\text { patients and } \\
\text { assist with } \\
\text { transfers on to } \\
\text { bike }\end{array}$ & $\begin{array}{l}\text { Great form of } \\
\text { exercise, different } \\
\text { types of bikes } \\
\text { (some seated low } \\
\text { to the ground, } \\
\text { some in a more } \\
\text { upright chair } \\
\text { position), cycled } \\
\text { for as far as they } \\
\text { wanted with a } \\
\text { time to turn back } \\
\text { around and be } \\
\text { back by, on a } \\
\text { Saturday so } \\
\text { community }\end{array}$ \\
\hline
\end{tabular}




\begin{tabular}{|c|c|c|c|c|c|}
\hline & & & & & $\begin{array}{l}\text { members able to } \\
\text { participate }\end{array}$ \\
\hline $2 / 10$ & $\begin{array}{l}\text { Seated } \\
\text { kickboxing }\end{array}$ & $\begin{array}{l}\text { At Casa Colina in } \\
\text { the OT room, had } \\
\text { chairs if needed, } \\
\text { TV provided in } \\
\text { room to watch } \\
\text { YouTube video off } \\
\text { of }\end{array}$ & $\begin{array}{l}\text { Room is } \\
\text { small so if a } \\
\text { lot of } \\
\text { participants } \\
\text { or a lot of } \\
\text { wheelchairs } \\
\text { can be a } \\
\text { squeeze }\end{array}$ & $\begin{array}{l}\text { Adapted for all } \\
\text { participants to be } \\
\text { able to } \\
\text { participate, } \\
\text { utilize a video so } \\
\text { can pause it to } \\
\text { take a break }\end{array}$ & $\begin{array}{l}\text { Not only a form } \\
\text { of physical } \\
\text { exercise, can also } \\
\text { be used to follow } \\
\text { directions, } \\
\text { encourage others, } \\
\text { build endurance }\end{array}$ \\
\hline $2 / 10$ & $\begin{array}{l}\text { Driving } \\
\text { range }\end{array}$ & $\begin{array}{l}\text { Putting green is on } \\
\text { grass, driving } \\
\text { range stand on } \\
\text { concrete to hit ball }\end{array}$ & $\begin{array}{l}\text { Difficult for } \\
\text { wheelchair } \\
\text { user to go to } \\
\text { driving } \\
\text { range }\end{array}$ & $\begin{array}{l}\text { Can easily adapt } \\
\text { on putting green } \\
\text { to make it easier } \\
\text { or more } \\
\text { challenging, can } \\
\text { be an } \\
\text { independent or } \\
\text { social sport }\end{array}$ & $\begin{array}{l}\text { Can get supplies } \\
\text { at location, more } \\
\text { of an independent } \\
\text { sport, many body } \\
\text { mechanical } \\
\text { factors in activity }\end{array}$ \\
\hline $2 / 24$ & $\begin{array}{l}\text { Seated } \\
\text { aerobics }\end{array}$ & $\begin{array}{l}\text { At casa Colina in } \\
\text { OT room, had } \\
\text { chairs if needed, } \\
\text { TV provided in } \\
\text { room to watch } \\
\text { YouTube video off } \\
\text { of }\end{array}$ & $\begin{array}{l}\text { Room is } \\
\text { small so if a } \\
\text { lot of } \\
\text { participants } \\
\text { or a lot of } \\
\text { wheelchairs } \\
\text { can be a } \\
\text { squeeze }\end{array}$ & $\begin{array}{l}\text { Easily adaptable, } \\
\text { very intense } \\
\text { workout, video } \\
\text { encouraging to } \\
\text { do whatever is } \\
\text { possible, fast } \\
\text { paced }\end{array}$ & $\begin{array}{l}\text { Great way for } \\
\text { adaptation and } \\
\text { indoor activity } \\
\text { that provides a } \\
\text { good workout, } \\
\text { can accommodate } \\
\text { to anyone, online } \\
\text { videos good } \\
\text { resource because } \\
\text { can always } \\
\text { change it up }\end{array}$ \\
\hline $2 / 26$ & $\begin{array}{l}\text { Rock } \\
\text { climbing }\end{array}$ & $\begin{array}{l}\text { Went to a facility } \\
\text { in L.A., limited } \\
\text { parking available, } \\
\text { mats once in the } \\
\text { gym }\end{array}$ & $\begin{array}{l}\text { Fear of } \\
\text { heights }\end{array}$ & $\begin{array}{l}\text { Great workout, } \\
\text { utilizes both } \\
\text { arms and legs, } \\
\text { social, } \\
\text { community type } \\
\text { of environment }\end{array}$ & $\begin{array}{l}\text { Many adaptations } \\
\text { can be made to } \\
\text { accommodate } \\
\text { different } \\
\text { disability, have } \\
\text { open gym nights } \\
\text { on Wednesdays, } \\
\text { can provide a } \\
\text { great community } \\
\text { dynamic, learn } \\
\text { how to } \\
\text { communicate } \\
\text { with person } \\
\text { holding you and }\end{array}$ \\
\hline
\end{tabular}




\begin{tabular}{|l|l|l|l|l|l|}
\hline & & & & & $\begin{array}{l}\text { to tie knot on } \\
\text { ropes }\end{array}$ \\
\hline
\end{tabular}


Appendix B

Survey Questions

Adaptive Sports Survey

1. Gender

$\square \quad$ Female

$\square \quad$ Male

$\square \quad$ Prefer not to say

2. Diagnosis of injury:

3. How long have you been participating in adaptive sports?

Less than 1 year

1-2 years

3-4 years

5-10 years

$\square$ More than 10 years

4. Did you participate in sports before your onset?

Yes Which sport(s)?

$\square$ No

5. On average, how often do you participate in adaptive sports?

$\square$ Once a week

$\square$ Twice a week

Three times a week

] Four times a week

$\square$ Five times a week

- Six times a week

$\square \quad$ Seven times a week

$\square$ Other:

6. What adaptive sports do you currently participate in?

$\square$ Basketball

$\square$ Football

$\square$ Tennis

$\square$ Volleyball

$\square$ Baseball/softball

Cycling

- Dance

Swimming

- Surfing

$\square$ Kayaking 
$\square$ Rock climbing

Horseback riding

Skiing

Other:

7. What adaptive sports are you interested in but do not currently participate in?

$\square \quad$ Basketball

$\square$ Football

$\square$ Tennis

$\square$ Volleyball

$\square$ Baseball/Softball

Cycling

$\square$ Dance

$\square$ Swimming

Surfing

Kayaking

Rock climbing

$\square$ Horseback riding

$\square \quad$ Skiing

None

$\square$ Other:

8. What barriers are in the way of your participation in adaptive sports? (Check all that apply)

Cost

$\square$ Transportation

Equipment

Facilities far away

Lack of available sports

Not aware of available programs

Time

Difficulty exercising because of disability

Not enough energy

Not comfortable with participating

Having fear of injury

Being dependent on others

None

Other:

9. What were the reasons to participate in adaptive sports? (Check all that apply)

Previously participated

$\square$ Increase health and fitness

$\square$ Fun

$\square$ Increase strength

$\square$ Social atmosphere 
Increase self confidence

Learning new skills

Competition

Increase independence

$\square$ Other:

10. What is your usual mode of transportation?

G Car

B Bus

$\square$ Uber/lyft

$\square \quad$ Ride from friend

$\square$ Other:

11. How satisfied are you with your health? (Check which applies)

Not satisfied

Somewhat satisfied

Satisfied

Very satisfied

12. How satisfied are you with your quality of life? (Check which applies)

Not satisfied

Somewhat satisfied

Satisfied

Very satisfied

13. Do you think participation in adaptive sports has helped you participate in other activities?

$\square$ Yes

$\square$ No

$\square$ Maybe

14. As a result of participation in adaptive sports, do you feel... (Check the box that applies)

\begin{tabular}{|l|l|l|l|l|}
\hline & Less than before & About the same & Slightly more & $\begin{array}{l}\text { Significantly } \\
\text { more }\end{array}$ \\
\hline $\begin{array}{l}\text { More physically } \\
\text { active }\end{array}$ & & & & \\
\hline Happier & & & & \\
\hline Healthier & & & & \\
\hline More confident & & & & \\
\hline More mobile & & & & \\
\hline
\end{tabular}




\author{
Appendix C \\ Interview Questions
}

\title{
Participants
}

1. What is your diagnosis?

2. When did you start playing in adaptive sports? How did you get involved (hear and learn about programs)?

3. How long after your diagnosis did you start playing in adaptive sports?

4. What do you enjoy about playing?

5. How does it make you feel when playing sports?

6. What drives you to continue playing sports?

7. Have adaptive sports helped you find a role in your daily routine?

8. Have adaptive sports encouraged you to explore other occupations outside of sports?

9. What impact has adaptive sports played on your day to day life?

10. Has adaptive sports provided a sense of doing, being, becoming and/or belonging?

11. Did you encounter any barriers or notice any barriers now to accessing adaptive sports?
a. Environmental
b. Social
c. Personal
d. Distance

12. Any other comments or suggestions?

\section{Staff/Volunteers}

1. What role has adaptive sports played on the participants? 
2. Do you see any barriers to participants accessing sporting events or not being able to participate?

3. Do you think there is a problem with sustained participation? Why or why not?

4. What are some challenges to incorporate all athletes to participation?

5. Are there any additions or changes you would like to see with your program or facility?

6. Any other further suggestions or comments? 


\section{Appendix D}

Activity Analysis Example

\section{Activity analysis- Staff}

Therapeutic recreation program: Skiing- Big Bear, CA

Date: January 21

Group Size: 8

Types of attendants: TBI, SCI, community

Time required: entire day trip, left at 6 am, return 6 pm

Location: Big Bear, CA- utilized two vehicles to transport participants and volunteers

Equipment needed: none due to use of facilitators who provide equipment, Casa Colina

provides a list of items to bring for participants- ex. hat, sunglasses, gloves, water, lunch or lunch money

At location (USARC)- provide necessary equipment and instructors- snow boots, helmets, skiis, gloves if needed

Precaution- high altitude- can cause seizures, weight limit 200 pounds

\section{Skills required:}

\section{- Physical}

- Mod balance-

- Mod core strength

O Mod UE ROM- utilize UE with ski poles, assists with stabilization and balance

○ Weight shifting

- Muscle strength- skiing enables a full body workout and can help increase strength 
- Endurance- participants ski before and after lunch, building endurance

\section{- Cognitive}

- Attention- sustained attention, attention of surroundings

○ Temperament and personality- openness to experience, confidence, motivation

○ Memory- remembering tips and tricks to apply in next ski run or after lunch

\section{- Psychological}

○ Freedom

- in a new area

- out of wheelchair

- feeling of freedom when going down the hill

\section{- Social/communication}

- Communicating with instructor

○ Communicating amongst each other- encouraging, supporting

\section{Goals/objectives}

1. Set a goal to accomplish at the beginning of session, reassess goal at lunch and adapt if needed

2. If first time, set a goal of what to accomplish for the day

3. If very athletic or attended several times before can have a goal to use a different type of ski

\section{Impact of participation}

- Confidence

O One patient proud to make it down the hill without falling- first time skiing 
- Continue to improve and do better after lunch

- Motivation, improvement

- Whole body workout

- Participants sore after but feel good

- Many stated it was nice to go out to Big Bear and will want to return for the next trip

- Advocacy to program utilized in Big Bear and around the area for increase participation

D Difficulty with transportation

- Benefits to participation

○ Strength

○ Problem solving

○ Attention

\section{Potential for grading}

- Utilization of different types of skis

- Mono ski- seat on top of one ski, requires upper body strength and control

- Bi ski- seat on top of two ski, requires upper body strength and control, but less than a mono ski

- Standing- feet on two separate skis, requires control of both skis, balance, strength, forward lean, posture

- Use of tethers with instructors to make it easier or more difficult

- Different difficulty on slopes

\section{Observations}

- Wide stance for better BOS 
- Lean forward slightly

- Adjustments on leaning and maneuvering for easier route

- Instructors used tipper tension, and waist band to control patient

- 2 instructors per 1 participant

- Loading on to ski lift- one instructor on each side, need to lift up chair and place on lift

- Volunteers go through training

- Align body in sit ski- can utilize foam padding of needed but not always recommended

\section{Activity analysis- Participants}

Therapeutic recreation program: Skiing- Big Bear, CA

Date: January 21

Group Size: 8

Types of attendants: TBI, SCI, community

Time required: entire day trip, left at 6 am, return 6 pm

Location: Big Bear, CA- utilized two vehicles to transport participants and volunteers

Equipment needed: none due to use of facilitators who provide equipment, Casa Colina

provides a list of items to bring for participants- ex. hat, sunglasses, gloves, water, lunch or lunch money

At location (USARC)- provide necessary equipment and instructors- snow boots, helmets, skiis, gloves if needed

Precaution- high altitude- can cause seizures, weight limit 200 pounds

\section{Skills required:}




\section{- Physical}

- Balance

$\circ$ Core strength

- Upper extremity range of motion- when using ski poles

- Weight shifting- to change direction when going down slope

○ Muscle strength

- Endurance- ski in the morning, take a break for lunch, ski after lunch

\section{- Cognitive}

- Following directions

- Understanding the limits of your body- when to take a break, when to stop

- Remembering tips and tricks to apply in next ski run or after lunch

\section{- Psychological}

○ Freedom

- in a new area

- out of wheelchair

- feeling of freedom when going down the hill

\section{- Social/communication}

○ Communicating with instructor

○ Communicating amongst each other- encouraging, supporting

\section{Goals/objectives}

1. Set a goal to accomplish at the beginning of session, reassess goal at lunch and adapt if needed

2. If first time, set a goal of what to accomplish for the day 
3. If very athletic or attended several times before can have a goal to use a different type of ski

\section{Impact of participation}

- Confidence

O One patient proud to make it down the hill without falling- first time skiing

○ Continue to improve and do better after lunch

- Motivation, improvement

- Whole body workout

- Participants sore after but feel good

- Many stated it was nice to go out to Big Bear and will want to return for the next trip

- Advocacy to program utilized in Big Bear and around the area for increase participation

- Difficulty with transportation

- Benefits to participation

Strength

○ Problem solving

○ Attention

\section{Potential for grading}

- Utilization of different types of skis

- Mono ski- seat on top of one ski, requires upper body strength and control

- Bi ski- seat on top of two ski, requires upper body strength and control, but less than a mono ski 
○ Standing- feet on two separate skis, requires control of both skis, balance, strength, forward lean, posture

- Use of tethers with instructors to make it easier or more difficult

- Different difficulty on slopes

\section{Observations}

- Wide stance for better BOS

- Lean forward slightly

- Adjustments on leaning and maneuvering for easier route

- Instructors used tipper tension, and waist band to control patient

- 2 instructors per 1 participant

- Loading on to ski lift- one instructor on each side, need to lift up chair and place on lift

○ Volunteers go through training

Align body in sit ski- can utilize foam padding of needed but not always recommended 


\section{Appendix E}

\section{Sports Interest Checklist}

This sports interest checklist is a way to identify the array of different sports that participants may be interested in. The column on the right can be a way to categorize sports that they are interested in, not interested in, or potentially interested in trying. The participant can simply write "yes", "no", or "maybe" in the column to sort out the different sports listed below.

Sports interest checklist

\begin{tabular}{|l|l|}
\hline \multicolumn{1}{|c|}{ Sport } & \\
\hline Walking & \\
\hline Dancing & \\
\hline Golf & \\
\hline Football & \\
\hline Swimming & \\
\hline Bowling & \\
\hline Checkers/chess & \\
\hline Wrestling & \\
\hline Cycling & \\
\hline Billiards & \\
\hline Tennis & \\
\hline Basketball & \\
\hline Fishing & \\
\hline Baseball/softball & \\
\hline Surfing & \\
\hline Horseback riding & \\
\hline Soccer & \\
\hline Esports & \\
\hline Skiing & \\
\hline Snowboarding & \\
\hline Volleyball & \\
\hline
\end{tabular}




\begin{tabular}{|l|l|}
\hline Kayaking & \\
\hline Rock climbing & \\
\hline Hockey & \\
\hline Rugby & \\
\hline Pickleball & \\
\hline Other & \\
\hline
\end{tabular}

Flashcards example: An addition to the sports interest checklist as a different resource to be utilized to identify sports wished to participate in.

Front

Swimming

Front

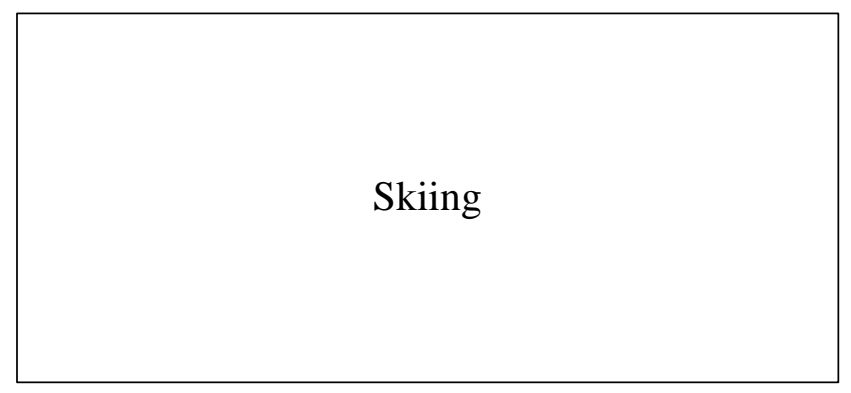

Front

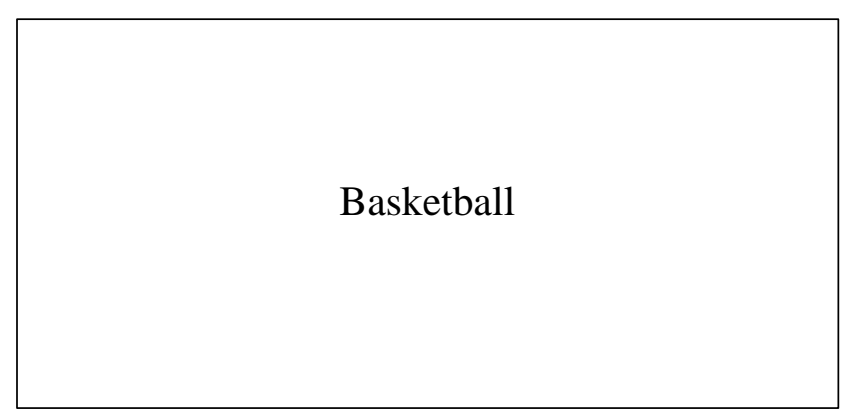

Back

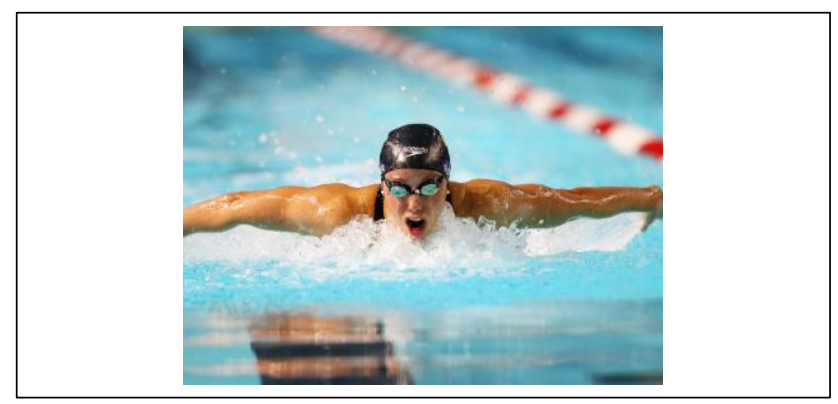

Back
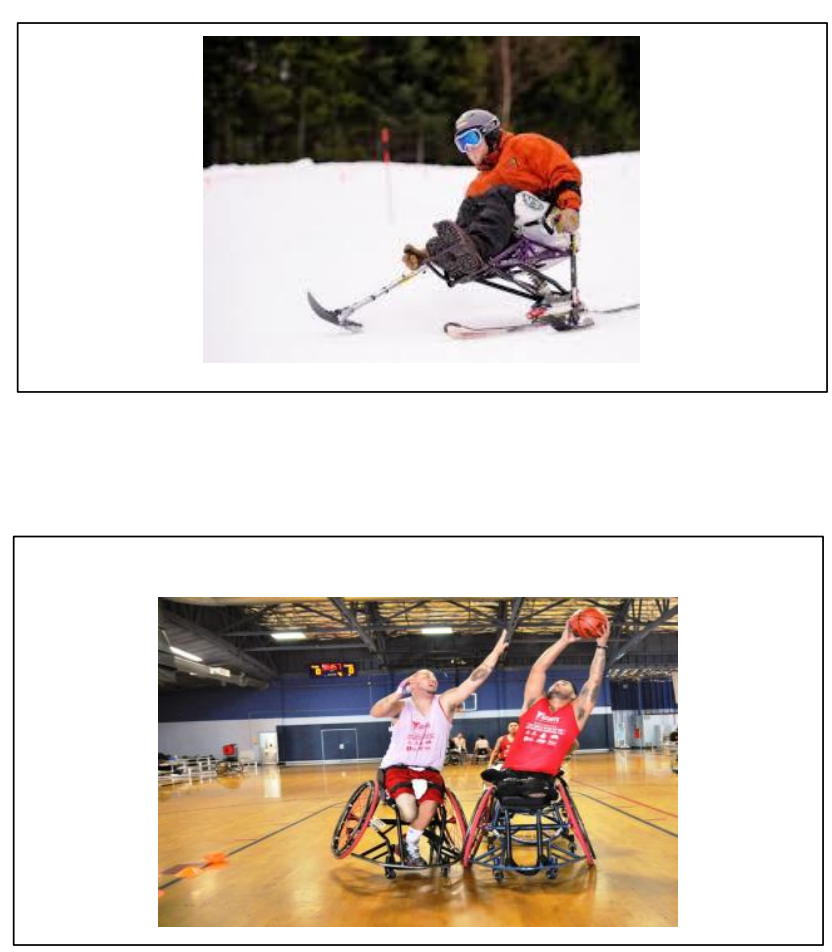


\section{Appendix F \\ Intake Form}

Intake Form

1. What is your history of playing sports?

2. What sports are you interested in?

3. What are your personal interests and values?

4. What is your current daily routine?

5. Do you have any concerns related to engaging in participation?

6. What are your strengths and limitations in participating in sports?

7. Is there any medical history that should be identified that could potentially impact your ability to participate?

8. What are your priorities and desired goals and outcomes? 
Appendix G

Presentation of Findings

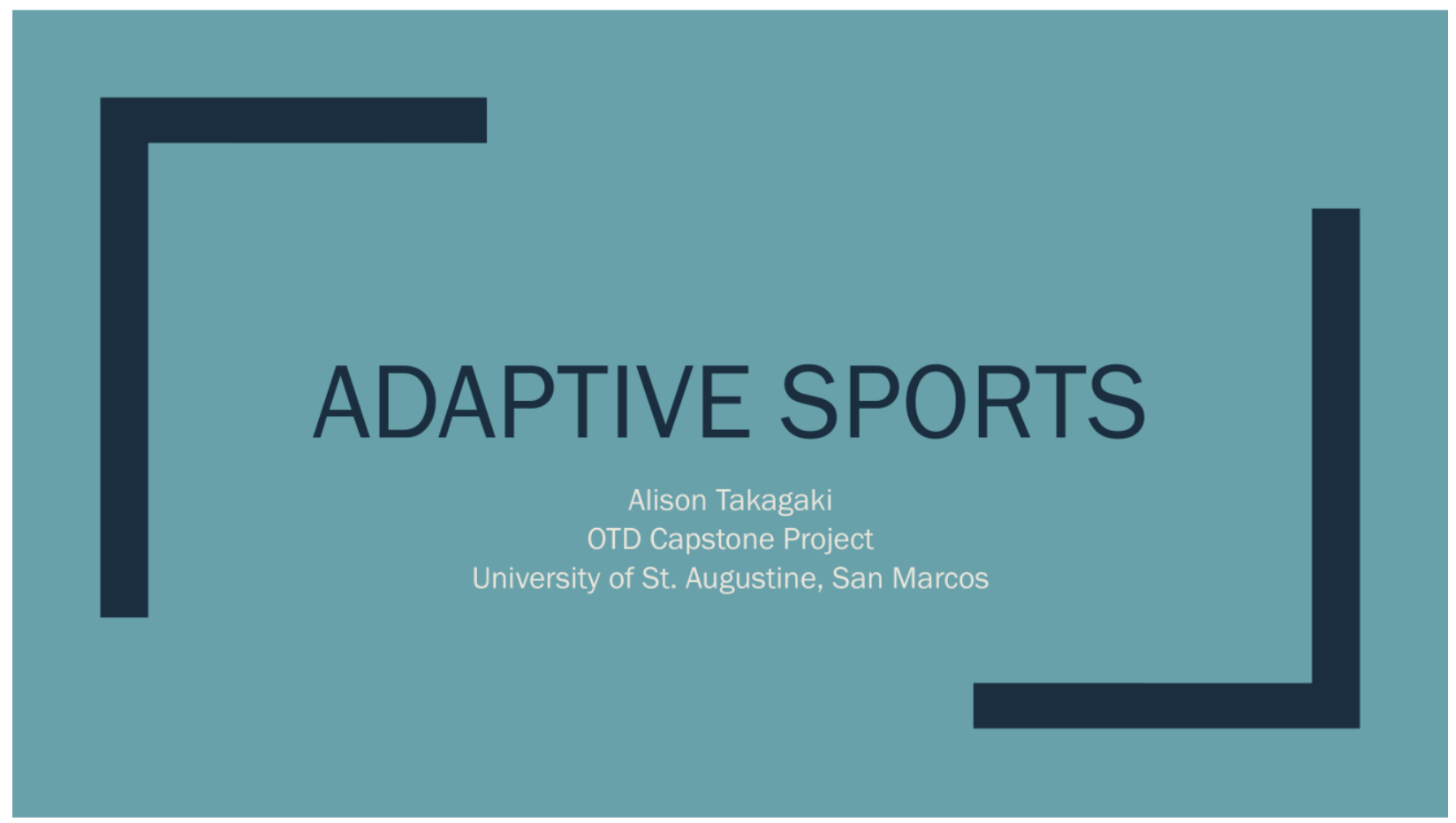

\section{Literature Review}

- Awareness (Aytur et al., 2018)

- Not well known

- Small towns, schools

- Location (Lape et al., 2018)

- Travel time

- Cost

- Factors (Jaarsma et al., 2014)

- Personal

- Environmental

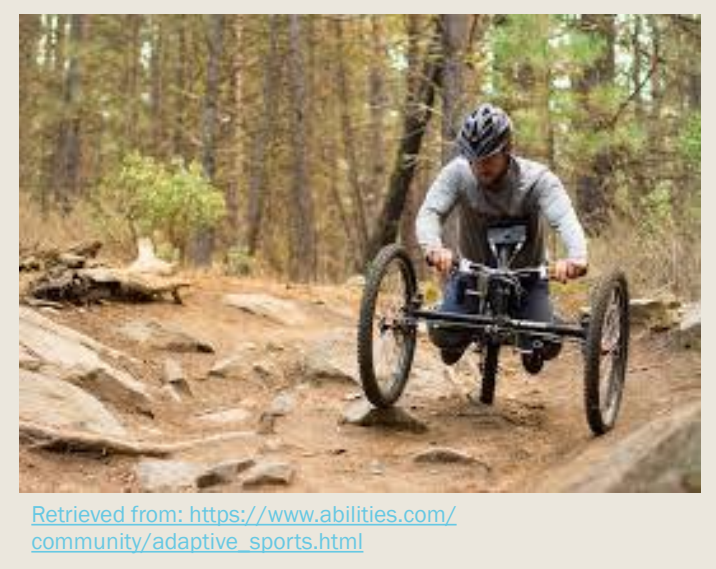




\section{Significance}

- Physical activity

- Joining a team

- Social

engagement/support team

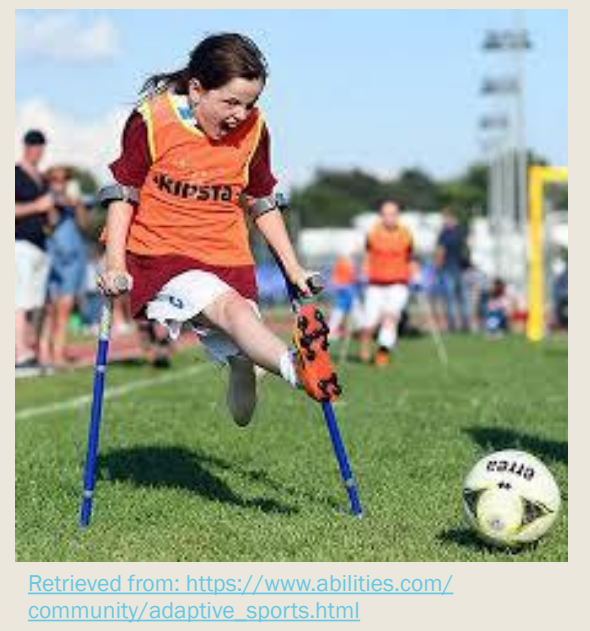

\section{My Project}

- Goal: To improve awareness and access to adaptive sports

- Understand barriers and facilitators to adaptive sports

- Complete activity analysis on different sports

- Complete surveys and interviews to gain a deeper understanding

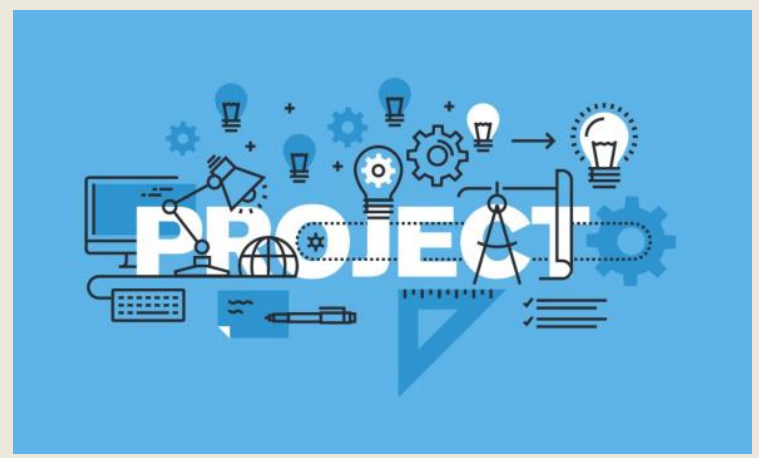




\section{My Experience}

- Worked with Recreational Therapy and Outdoor Adventures Program

- Observed an array of different sports

- Understood impact of Recreational Therapy

- Provided insight on my future career

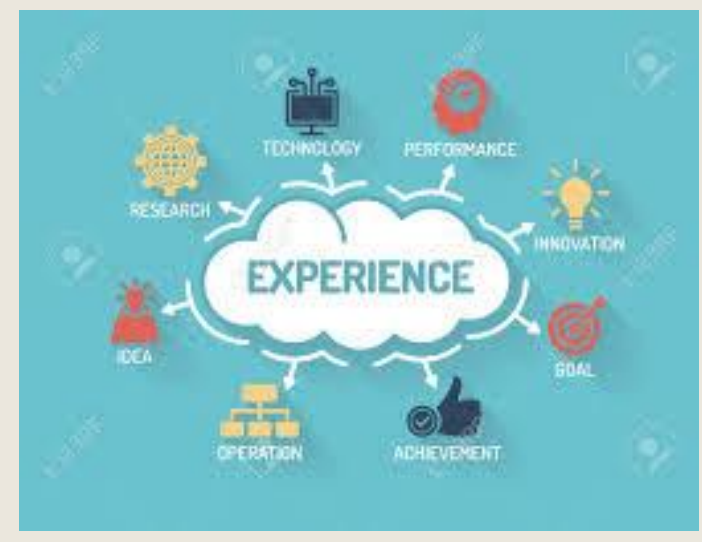

\section{Findings- Barriers}

- Difficulties with transportation

- Finding accessible programs

- Competitive level/ classifications

- Equipment/ accessing equipment

- Environmental factors

- Restrooms

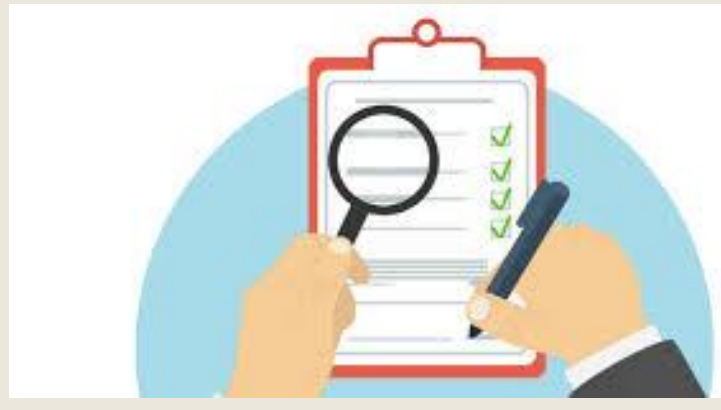

- Terrain 


\section{Findings- Facilitators}

- Learning new skills

- Competition

- Fun

- Friendships

- Freedom

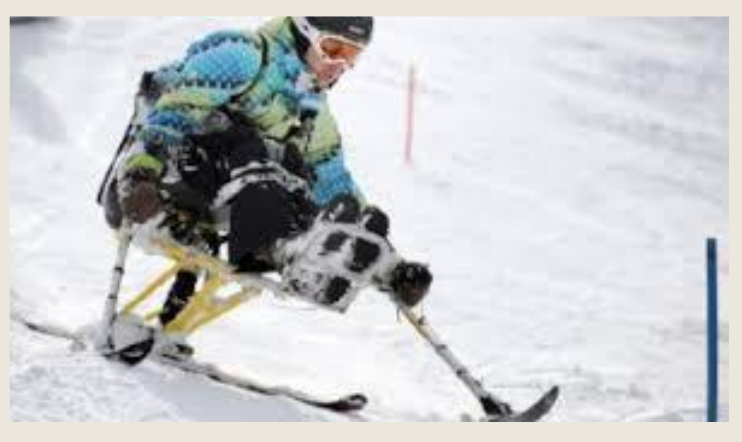

- Confidence

\section{OT Impact}

- Activity analysis

- Adaptive equipment, modifications

- Environmental factors

- Rules of game

- Returning or learning meaningful occupations

- Health benefits

- Developing friendships

- Enhance well-being

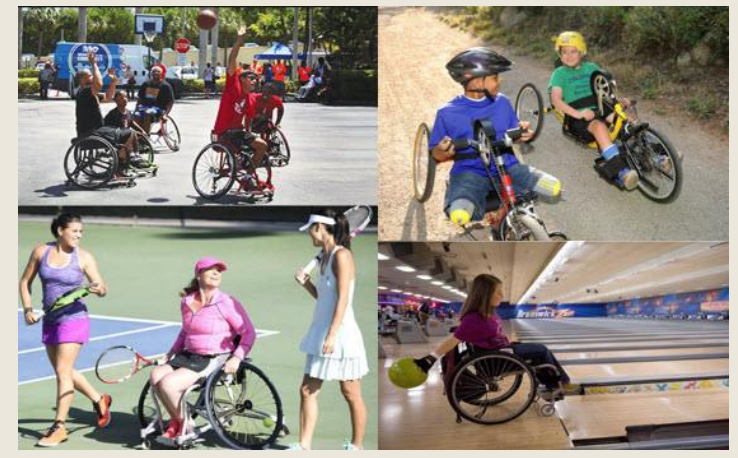

- Advocacy 


\section{Future Implementations}

- Collaboration

- Education to programs and participants

- Internet resources/ brochures

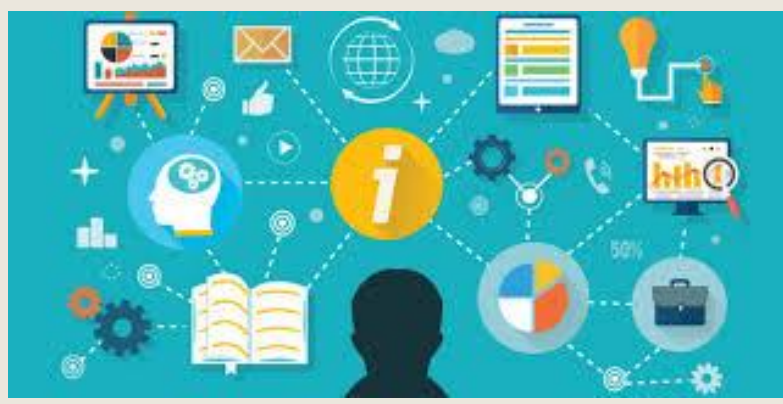

- Advocacy

\section{Thank you! Questions?}
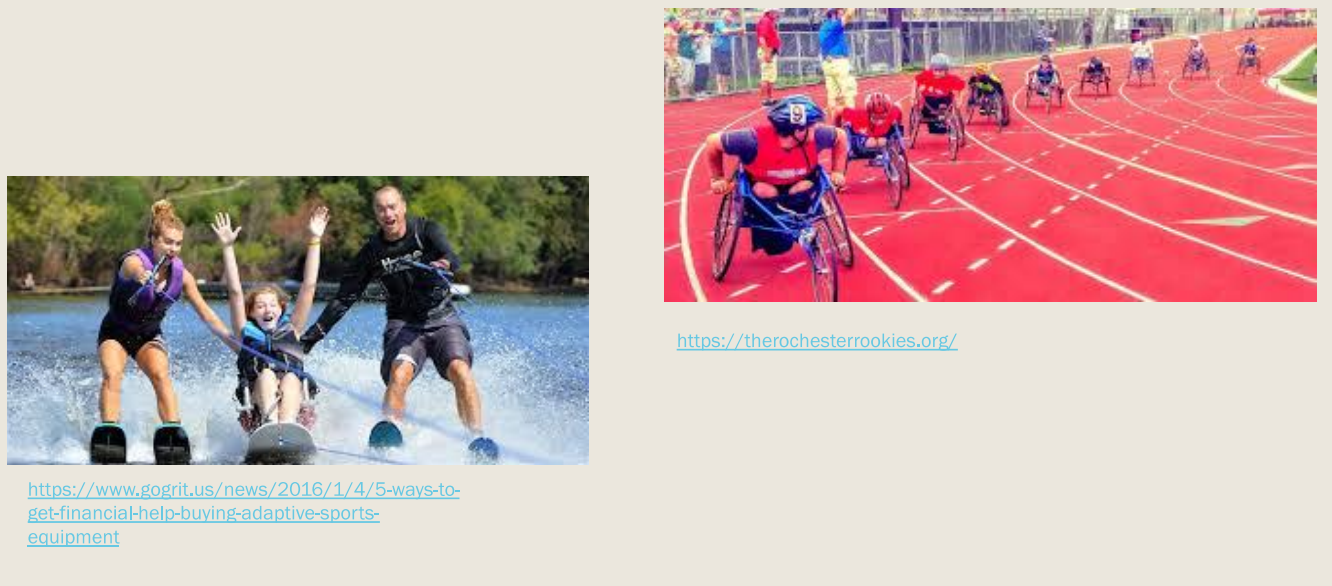

hittos://therochesterrookies.org/ 


\section{References}

- $\quad$ Aytur, S., Craig, P. J., Frye, M., Bonica, M., Rainer, S., Hapke, L., \& McGilvray, M. (2018). Through the lens of a camera: Exploring the meaning of competitive sport participation among youth athletes with disabilities. Therapeutic Recreation Journal, 52(2), 95-125. Retrieved from hitto://p12-

- Jaarsma, E. A., Dijkstra, P. U., Geertzen, J. H. B., \& Dekker, R. (2014). Barriers to and facilitators of sports participation for people with physical disabilities: A systematic review. Scandinavian Journal of Medicine \& Science in Sports, 24(6), 871-881. Retrieved from

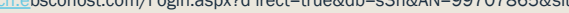

- Lape, E. C., Katz, J. N., Losina, E., Kerman, H. M., Gedman, M. A., \& Blauwet, C. A. (2018). Original research: Participant-reported benefits of involvement in an adaptive sports program: A qualitative study. $P M \& R, 10,507-515$. Retrieved from hittos://doi-org.prxusa.lirn.net/10.1016/i.pmrl.2017.10.008 